CIHM

Microfiche

Series

(Monographs)
ICMH

Crllection de microfiches (monographies)

Canadian Institute for Historical Microreproductions / Institut canadien de microreproductions historiques
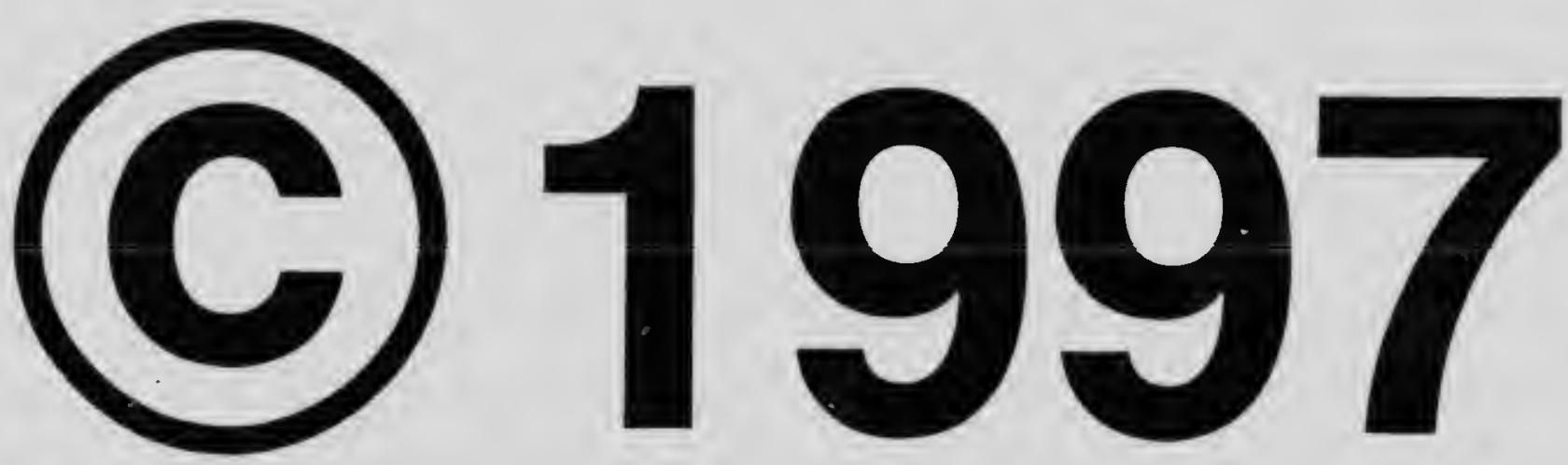


\section{Technical and Bibliographic Notes / Notes techniques et bibliographiques}

The Institute has attempted to obtain the best original copy available for filming. Features of this copy which may be bibliographically unique, which may alter any of the images in the reproduction, or which may significantly change the usual method of filming are checked below.

$\checkmark$ Coloured covers /

Couverture de couleur

Covers damaged /

Couverture endommagée

Covers restored and/or laminated /

Couverture restaurée etlou pelliculée

Cover title missing / Le titre de couverture manque

Coloured maps / Cartes géographiques en couleur

Coloured ink (i.e. other than blue or black) /

Encre de couleur (i.e. autre que bleue ou noire)

Coloured plates and/or illustrations /

Planches et/ou illustrations en couleur

Bound with other material /

Relié avec d'autres documents

Only edition available /

Seule édition disponible

Tight binding may cause shadows or distortion along interior margin / La reliure serrée peut causer de l'ombre ou de la distorsion le long de la marge intérieure.

Blank leaves added during restorations m.ay appear within the text. Whenever possible, these have been omitted from filming / II se peut que certaines pages blanches ajoutées lors d'une restauration apparaissent dans le texte, mais, lorsque cela était possible, ces pages n'ont pas été filmées.

Additional comments /

Commentaires supplémentaires:
L'Institut a microfilmé le meilleur exemplaire qu'il lui a été possible de se procurer. Les détails de cet exemplaire qui sont peut-être uniques du point de vue bibliographique, qui peuvent modifier une image reproduite, ou qui peuvent exiger une modification dans la méthode normale de filmage sont indiqués ci-dessous.

Coloured pages / Pages de couleur

Pages damaged / Pages endommagées

Pages restored and/or laminated /

Pages restaurées et/ou pelliculées

Pages discoloured, stained or foxed /

Pages décolorées, tachetées ou piquées

Pages detached / Pages détachées:

Showthrough / Transparence

Quality of print varies I

Qualité inégale de l'impression

Includes supplementary material /

Comprend du matériel supplémentaire

Pages wholly or partially obscured by errata slips, tissues, etc., have been refilmed to ensure the best possible image / Les pages totalement ou partiellement obscurcies par un feuillet d'errata, une pelure, etc., ont été filmées à nouveau de façon à obtenir la meilleure image possible.

Opposing pages with varying colouration or discolourations are filmed twice to ensure the best possible image / Les pages s'opposant ayant des colorations variables ou des décolorations sont filmées deux fois afin d'obtenir la meilleure image possible.

This item is flimed at the reduction ratio checked below I

Ce document est filmé au taux de réduction indlqué ci-dessous.

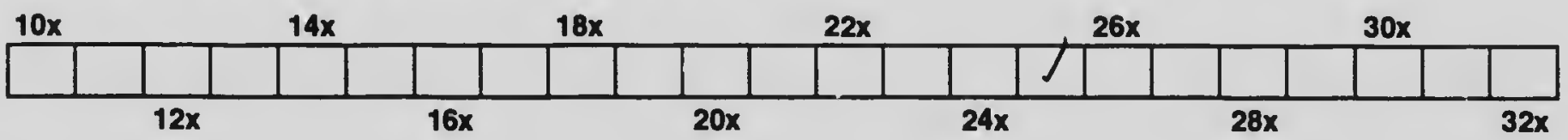


The copy filmed here hes been reproduced thanks to the generosity of:

National Library of Canada

The images eppaering here are the bast quality possible considaring the condition and legibillty of the original copy and in keoping with the filming contract spocifications.

Originel copies in printed peper c.2vers ere fllmed beginning with the front cover and anding on the last pege with a printed or illustreted impression, or the beck cover when eppropriete. All other original copies sre filmed beginning on the first poge with a printed or lllustretad impres. sion. end ending on the lest page with a printsd or illustrated impression.

The lest racordad frame on each microfiche shell contain the symbol $\longrightarrow$ Imeening "CON. TINUED"). or the symbol $\nabla$ (meaning "END"). whichaver applias.

Mups. pletes, chans. etc., may be filmad ot differant raduction ratios. Those 800 lerge 80 be ensiraly included in one exposure are filmed beginning in the upper latt hand cornar. laft to righe and top to botsom, as many fremes as raquirad. The following diagrams illustrate the method:
L'exemplaire filmo fut reproduit gràce la génórosité do:

Bibliothèque nationale du Canada

Les imagas suiventas ont bte raproduites avec is plus grand soin. compte tanu da la condition et de le nartere de l'axemplaire filme. at an conformite avec los conditions du contrst de fllmege.

Les examplairas originaux dont la couvartura an popiar ast imprimbe sont filmds an commençant per lo premier plot et an terminent soit par la darnidra pege qui componte una emprainte d'imprassion ou d'illustration, soit par la second plat, salon lo cas. Tous las autras exemplairos originaux sont filmbs an commancont par la pramiora page qui comporte una amprainta d'imprassion ou d'lllustration of an terminant par le derniore poge qui comporte une talle emprointe.

Un des symboles suivents apparoitre sur la darniore imsge de cheque microticha. salon la cas: le symbola $\longrightarrow$ signifia "A SUIVRE". Io symbole $\nabla$ signifie "FIN".

Las cartos, plenches, toblaaux, etc.. peuvant otra filmes das toux de roduction difforents.

Lorsqua lo document est trop grend pout ète roproduit on un soul cliche. il est filme a partir de l'engle supdrieur gouche. de gauche droite. ot de hout an les. on pranant la nombra d'imagea nocasseire. Les diagrammes suivants lllustrant la mothoda.
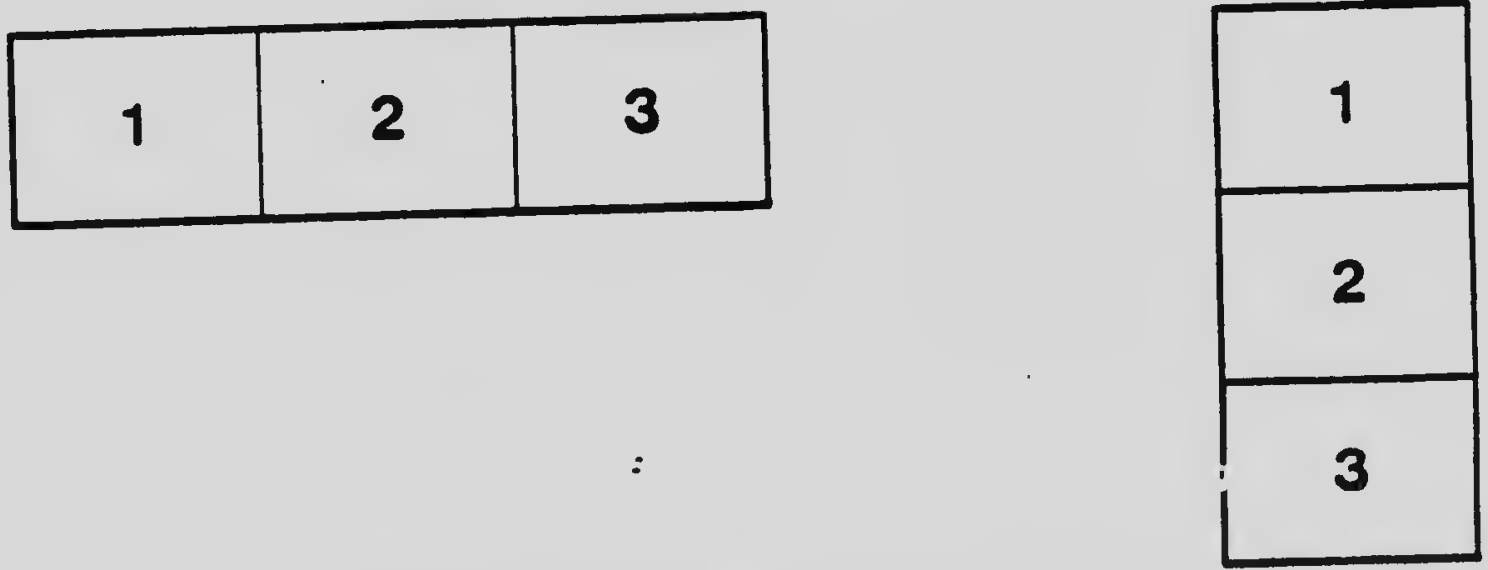

\begin{tabular}{|l|l|l|}
\hline 1 & 2 & 3 \\
\hline 4 & 5 & 6 \\
\hline
\end{tabular}


MICROCOPY RESOLUTION TEST CHART

(ANS: and ISO TEST CHART No. 2)
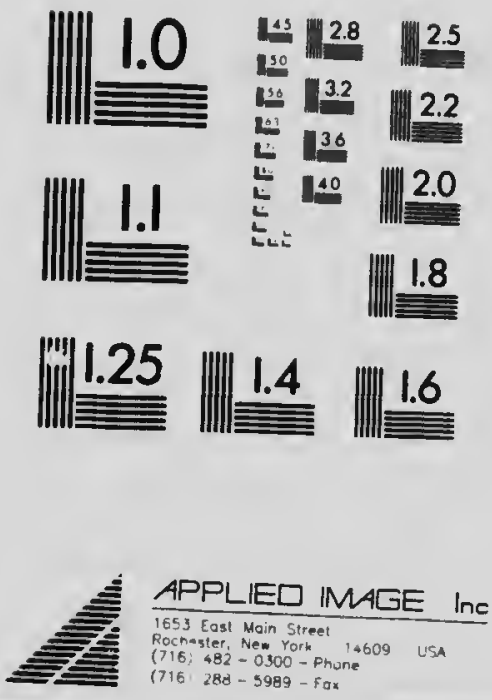


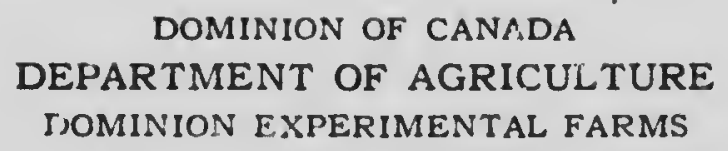

T JBACCO DIVISION

\title{
SUMMARY OF THREE YEARS EXPERIMENTS ON THE TOBACCO STATION AT HARROW, ONT.
}

\author{
BY \\ D. D. DIGGES, B.A., M.S.A., Superintendent.
}

BULLETIN 41 -Second Series. 


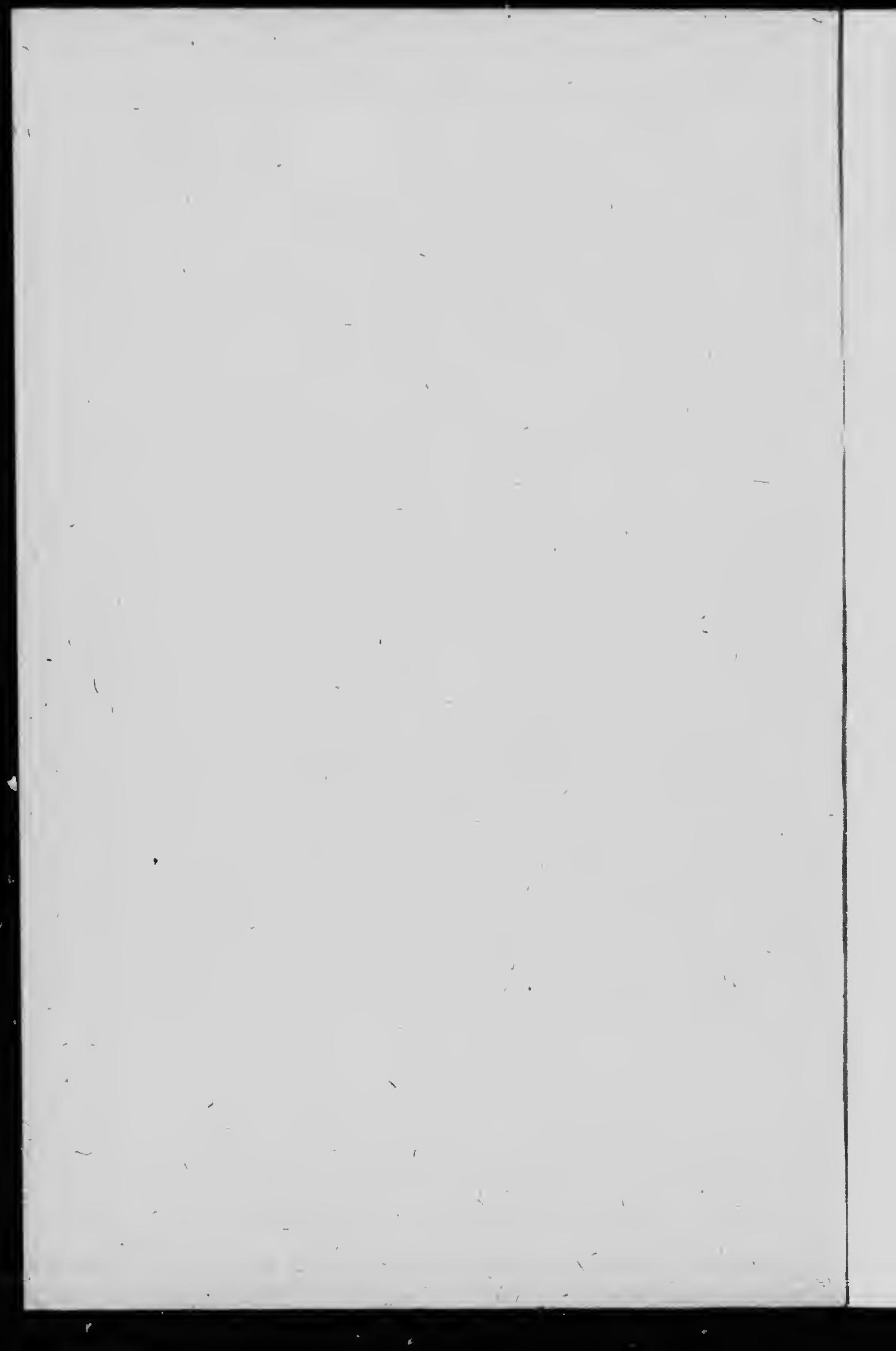




\author{
DOMINION OF CANADA \\ DEPAR'TMENT OF AGRICULTURE \\ DOMINION EXPERIMENTAL FARMS
}

TOBACCO DIVISION

\title{
SUMMARY OF THREE YEARS EXPERIMENTS ON THE TOBACCO STATION AT HARROW, ONT.
}

BY

D. D. DIGGES, B.A., M.S.A., Superintendent.

BULLE,TIN 41 -Second Series. 


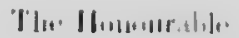

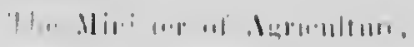

(111:)

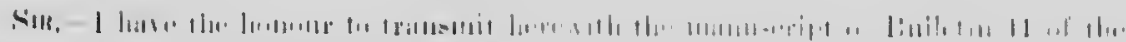

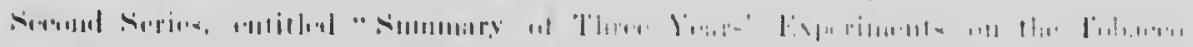

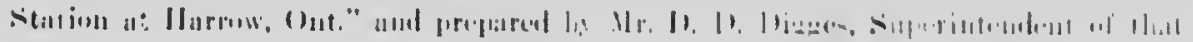
Sita.in.

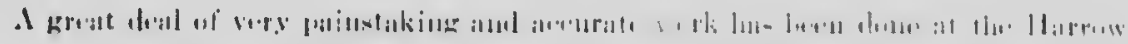

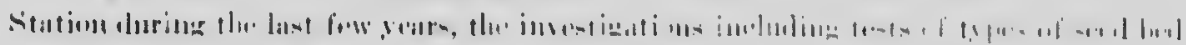

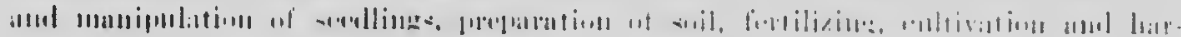

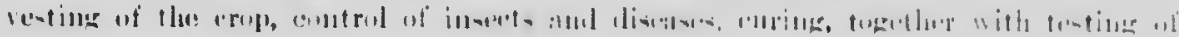
vardeticen and work in plant breding.

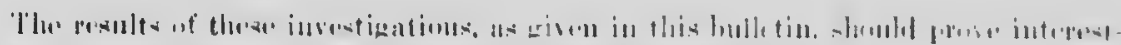

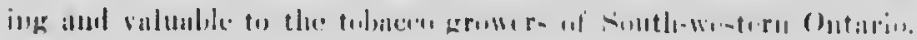

I have the hrountr th he, sir.

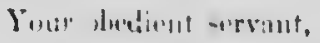

li. S. . MR'1111:11.11.

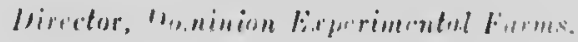


TABLE OF CORTENTS.

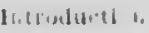

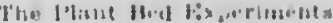

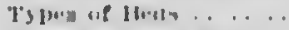

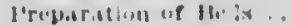

Firtllizina ......

Sterblikition ......

Similitik

Waterink . .

หhadlak .......

Voutllitins ........

Cit rol uf ingatang

Hiarde:ulux of

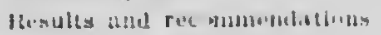

H.hatlons .... . . .............

spring l'reparation of the sull

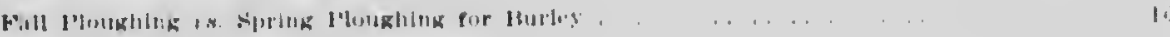

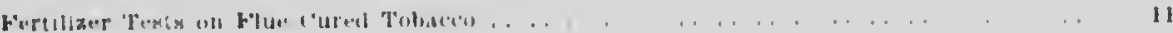

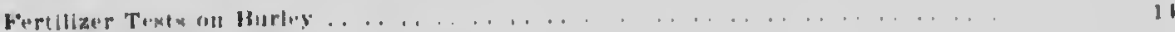

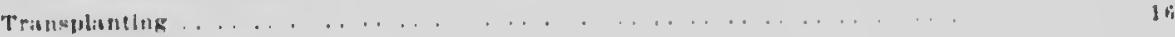

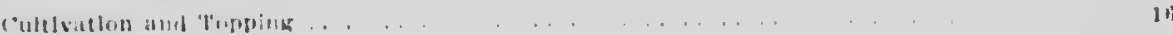

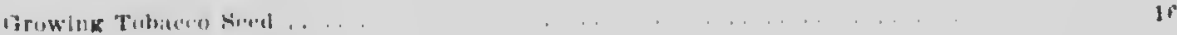

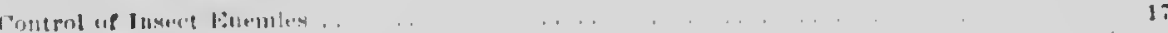

Cut Worm ....... . . . . . . . . . . . . . . . 18

The Hurn Wurm , . . . . . . . . . . . . . . . . . .

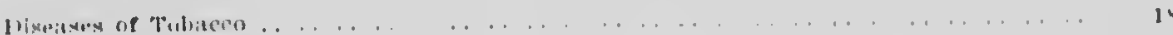

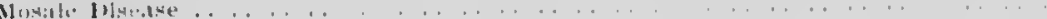

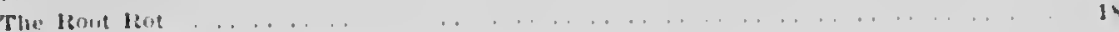

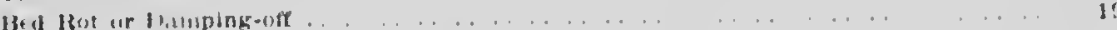

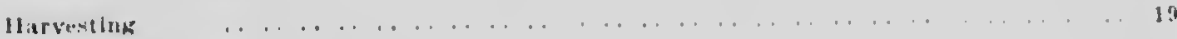

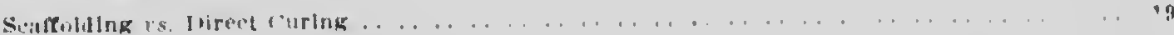

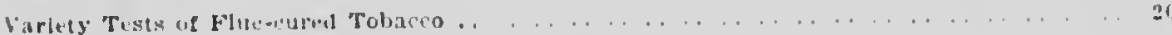

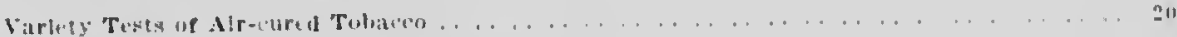

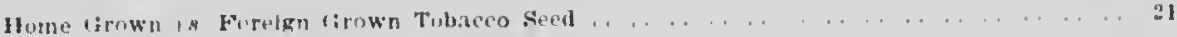

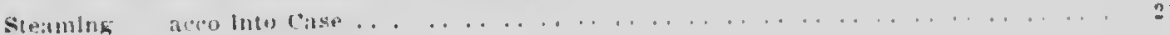




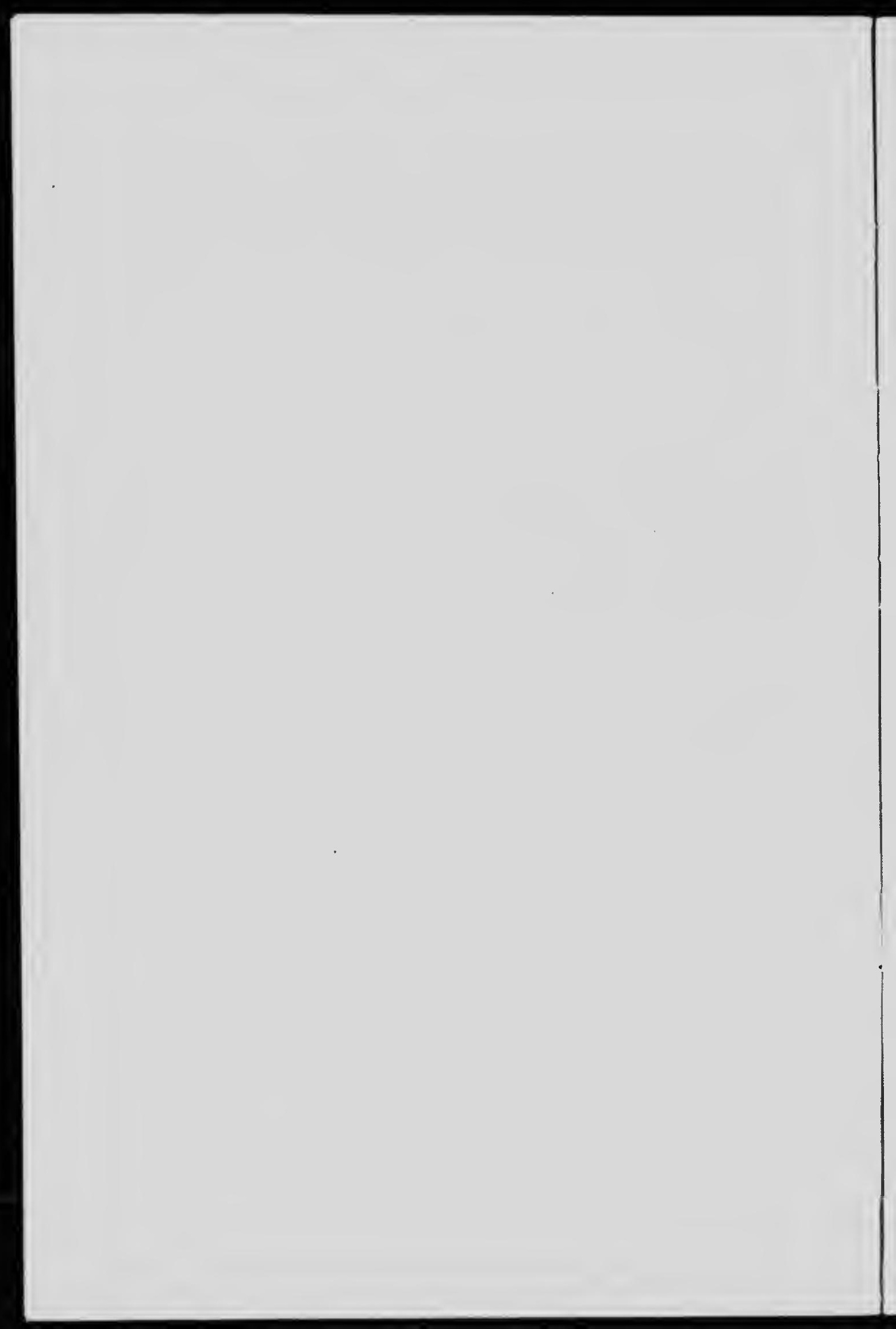




\title{
SUMMARY OF THREE YEARS EXPERIMENTS WITH TOBACCO ON THE TOBACCO STATION AT HARROW. ONT.
}

\author{
BY D. U. Dirges, B.S.A., M.S.A.
}

\section{INTRODUCTION.}

The impetus given tubacen growing, in Ontario. during the past three sears, due to the increased demand and the food prices paid, has camsed quite an expansion in this line of farning. Naturally, many new growers hive eome into the fied amel the tendency with all of the growers is to produce as laree a repop as posible. However.

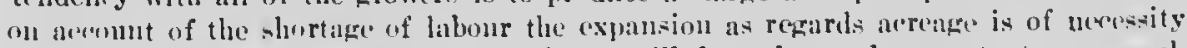
limited; and a preater production of tohacen will depend, to a large extent, upon each grower obtaining lurger yiulds from the sume aeraige than have been prolueed in the past. Noreorer, in order to maintain a stealy demtind for the home grown raw leaf it would seem advisable for the erowers. in pencenl. to inprove the quality of their proluct by using inprosed mether of enlture. Wist the alere facts in mind this paper is being mblished; and while wr realize that the results of experiments which have licen condueted for only three rears cill not be taken ton conclusirely we feel justified in publishing many of these results beranse of their chese similinity in years differing eonsiderably as to climatic rariations.

\section{Tif: Plant Bi:n Fippiminasts.}

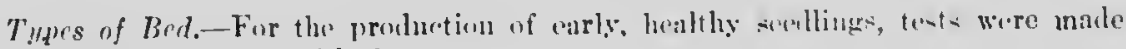
with the following types of bed:-

1. Cold bed, gluss eorered. fall stenmed.

2. Cold bed, glass corered, spring stesmed

3. Cold bed, canvas corered, spring ste:imul.

4. Ilot bed, glass eovered, spring steumerl.

5. Scmi-hot bed, glass eovered, spriug stemmed.

6. Semi-hot bed, eanvas rovered, syring stenmed.

Preparation of Beds.-In preparing the eold bed the nriginal suil, al sandy luam, was simply worked up and well pulverized.

The semi-hot bed was made ly diggring out a trench ahont cight inches deep into which straw, cornstalks, or any such mitterial wis platerel to al depth of six inches: after

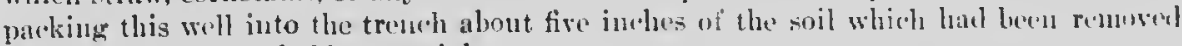
was placed on top of this mnterial.

After the beds liad been made a top dresing of two inehes of well rotted compost was applied. This compost was obtained from a swampy bush and was practically nothing but a mass of rotten veretable matter. Thr eompost was hauled the spring before it was to be used and was turned seversl times during the summer to insure its beirg well sunned and aired.

Fertilizing.-A portion of each bed was fertilized with sulphate of anmonia at tl.. rate of one ounce per square foot, and the fertilizer was well raked in just before sterit-

$04273-2 \frac{1}{2}$ 
izing. Other portions of the beds not fertilized hefure seeding were sprinkled with a solution consisting of $t w 0$ and one-half pounds of nitrate of soda to forty-seven gallins of water, at the riste of one gallon of the solution per eighteen suluare feet of bed, after the plants were up. $\Lambda$ portion of the beds was left unfertilized for eomparison.

Sterilization.-Two methods for sterilizing the beds were tested out; namely, with steilu ant with formulin and other ehemienl solutions.

In sterilizing with steam a galvanized iron pan or woden pan six fret wide. twelve teet long and wix inches denen was inverted over the soil, after it had been well loosened, and pulverized; the pan wis then enneeted to a biler in which the stoim was under one hundred pounds pressure, or more, and the stean turned on for thirty minutes. Some -e tions of the heds were steanul for forts-five mimutes and sixty minutes.

l'he formalin treatuent consisted of sprinkling the beal with a solntion of one part formalin to fifty parts water, at the rate of one gallon of the solution to two square feet of brd. The solution was put on in two applieations twenty-four hours apart. After each application the led was well eurcred with old bags to keep the funes of the formalin in. Twenty-four hours after the last applieation the hags were removed and the suil well loosened up to permit the fumes of the formalin to eseape. The bed was ready to le sown as soon as the fumes had escaped.

A prortion of each bed was left unsterilized for comparison.

The frames were placed aruund the beds as 8000 as they had been sterilized.

Secding.-The beds were seeded about $\Lambda_{\text {pril }} 15$, at different rates, with both dry seed and seed which had been eproniled. Loth home grown seed and foreign gruwu tobaceo seed was used. Dry sifted wuod ashes was mixed with the dry seed and rotten sawdust was mixed with the spronted seel to ant as carrier in sowing. Af ter being sown the seed was cuvered ly tamping the bed with a board and then sluiniling it with water.

Watering.-The beds were always kept just ninely moist after being seeded but were never tloodel. They were also well watered just before and after drawing the plants.

Shading. - Lnder glass the heds dried out very rapidly, on sumry dnys, while the plants were suall. Sinee the plants are very easily killed by drying when they first come up it was found beneficial to shade the bed somewhat by sprinkling the glass lightly with whitewash. IIowever, this must be removed after the plants eorer the beds with their leaves or there will be a tendeney for the plants to grow too sjindling and be too tender.

Ventilating.-Since a chang of air is ahouhtely neecsary for the proper development of the plants and as a means of holding disenses in eheck the glass eovered beds were ventilated a little every sumny day; and if fair days oecurred too infrequently they were rentilated a short while. alhout 1 rion, on eloudy days. The canvas covered beds were also ventilated occasionally; espeeialls on hot sultry days when there is langer of plants sinlling if this presiution is not taken. However, in ventilating, the temperature of the bed was not lowered much below eighty degrees Fahrenheit, if it cuuld be aroided, for fear of eleeking the growth of the plants. Ventilation was increased as the weather beeame warmer and as the plants inereased in size.

Control of Diseases. - The diseases of the seed bed were usually ersdieated by sterilizing the bed with steam. IIowever, in some instanees where the plants were a little too thick and the bed was kept a little too moist the bed rot or damping-off fungi would appear. This was thin controllcd ty throwing out the inferted plants and soil, giving all the rentilation posible, and allowing the bed to dry out for a day or so. 
Mardening-off.- About a weck before the plants were to be transplanterl, the lowl was permitted to dry out somewhat, and the canvas or glass was removed during the day and cren left off over niglit, if there was no danger of frost, in order to allow the plants to harden up.

Results and Recommendations.-(1) The glass envered beds always produecd plants ready for transplanting about two wceks earlicr than the canvas covered beds.

(2) The fall ste:tmed colel heel produed plants just as enrly and equally as thrifty as the spring steamed cold bed; and it is advisable to steam a portion of the beds in the fall as a safeguard against inelement springs.

(3) The glass covered lot bed produeed plants about thrce days earlier than an: other type of bed.

(4) The glass corered scini-lint bed produced plants from five to eight days carlier than the glass covered eold bed.

(5) The canvas eovered scmi-hot hed produeed plants about five days carlier than the cold bed similarly corered.

(B) The value of the semi-hot beal lies in its ahility to retain the heat absorbed for a longer period of time than the eold hed. The layer of straw or cornstalks stopped the eonduetion of the lieat from the five top inelies of soil to the lower layers of soil: and, as a result, the semi-lot bed not only did not cool off as rapidly as the eold bed but frequently the temperature of the former remainel from one to two degrees higher througlout the night than that of the latter.

( 7 ) The use of a eompost is reeommended as a top dressing for the bed. The compost is usually darker in eolour than the soil in the tobace growing seetions. therefore it absorhs more hent and holds the heat longer than the ordinary soils. Then too the rains and watering can not pack it too tightly for the proper development of the plants as is sometimes the ease witl ordinary soil.

(8) If elremieal fertilizers sueh as sulplinte of ammonia are to be applied to the bed before semling they hlould be sown on the loel several wroks before it is semled. in order to allow the soil moisture to dissolve and dilute the fertilizer before it contes into entact with the young plant.

(9) Two or three applientions of the nitrate ol soda solution proved rery beneficial in foreing the plants. IJowerer, the solution must nut be used too freel" or the: plants will he foreel too rapilly and will he too watery, weak, and spindling to stand the sloek of transplanting well. Care must be taken to sprinkle the plants witl pure water immediately after $n=i n g$ the nitrate of sola solution or it will burn then serionsly ant may kill them.

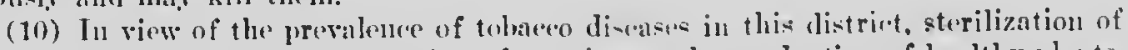
the seed bed is absolutely neesesary in orler to insure the production of lowiltly plants.

(11) Sterilization ly steaming is smerior to the use of chemicals. Stenminer not only kills the discases but the weeds as well and also leaves the soil in an exeellent nechanienl entition. $\Lambda$ bed ean usually le steaned for what it : ould eost to weed it onee.

(12) Plants were produeed eight days carlicr on atesmed soil than on soil which had been treated with chemieals: and from cight to cigliten diss earlier on steancd soil than on unsteamed soil.

(13) Steaming for thirty minutes at one hundred pounds pressure was apparently sufficient for weed and discase eradieation.

(14) Due to the faet that the high temperature to which the soil is raised temporarily in steaming renders enditions somewlat unfavourahle for plant growtli, it is recommended that the bed be steamed as long as possible before sceding.

(15) The steaming pan should only he deep enough to allow a small spaee between the top of the soil and the top of the pan for the passage of steam. If the pan is ton deep the stcan is not forced into the soil ur rupidly us with a more shallow pan and there is a greatur loss of steam hav condensation. 
(16) Although the sprouted eerd developed plants a little earlier than the dry seed very little was gained by using sprouted seed under glass. If the sced is sprouted it should be soaked just long enough for the tiny white gemmule to appear. Sprouting until the leaves derelop is a great mistake; many plants are killed in this manner and it is mueh more diffieult to get straight plants.

(17) The rate of seeding must he governed according to the germinative power of the seel. If sown dry, seel which germinat's about 85 per cent should be sown at the ratc of onc-seventl of au ounce (or a slightly henping teaspoonful) to one hundred square fuet of bed almut April fifteruth. IInwever, if the scel is sprouted, a little more shonid be used as it is ahnost imporsible not to kill some of them in the sowing operation.

(19) IIome grown seed gave plants ready for transplanting from three to seven lavs earlier than foreign grown seed.

\section{Rotations.}

For experimental purposes the land comprising the tobaceo station was divided and staked off into forty-one plots on which regular rotations were followed. An accurnte reeord was kept of the yields of all erops grown on these plots, also of all manures and fertillizcrs applied to them.

Four year zotations of corn, tobacco, cercals, and grass, tobreco, corn, ecrenls, and grass; three year rotations of tobncco, corn, and cereals; and five year rotations of tolnaceo, eorm, cere:ıls, and grass (two years) in the order named are being experiment $d$ with.

Due to the presence in the soil of the fungis Thielavia basicola Zopf., which eauses the root-rot of tobuceo, and the fact that red elover nunong other legumes is a host plant of this fungus, the growing of elover was entirely nbandoned. For hay a mixture of tincthy and red top was seeded.

\section{Spricig Preparation of tire Soll.}

All land for the production of tobaceo was well broken and pulverized witl the lise and harrows. The rows were then laid off at the desired width and the fertilizer drilled into the rows. Then the fertilizer was covered with a ridger which left the rows slightly clevated above the surrounding soil, thus minimizing the danger of the soung plints being drowned should a period of wet weather vecur. This ridge was gradually worked down during the process of eultivation until the land was praetically level again.

Beforc being broken, practically all land for the production of Burley lad an application of twelve tons of mauure per acre. No manure was applied to land to be used for the production of flue curerl tobacco.

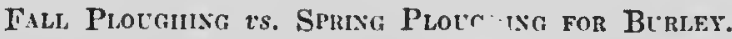

liach full two plots, each contnining one and. Ilf acres, were manured for the tohame erop to bo grown on those plots during the - lowing scason. Sometime after the first of October one lalf of each of those plots was ploughed, the other half remaining in sod. The following spring each of the fall ploughed sections was disced twice, at lifferent intervals, the last diseing constituting the preparation neeessary for planting; the sections remainir $r$ in sod were ploughed and disced once as a preparation for tobace. The tobarco on each sectivn of those plots was all fertilized alike, planted on the same day, eultivated alike, harrested on the same day, and every preeaution taken to make the time of ploughing the only factor affeeting the yield. When the tobacco was harvested the crop on each of the fall ploughed sections was tagged and kept separate from that on each of the spring ploughed sections until after it had been stripped and weighed. 
The results of this experiment will be found in the following tab!ns:-

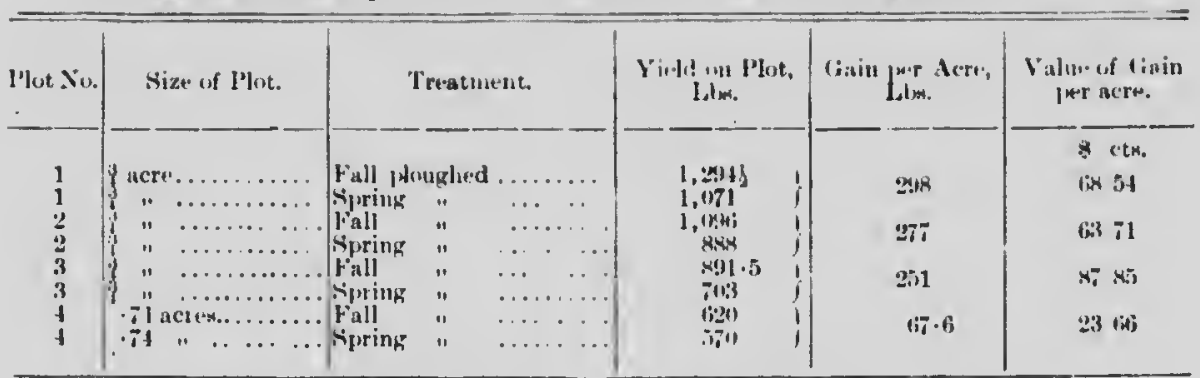

Jlots number 1 und 2 were growr in 917 , and plots 3 and 4 in 1918.

Conclusions.-(I) Fall manuring and ploughing for Burley is highly profitable

(2) The profit derived from fall ploughing is even greater than the mere increase in value of the crop ohiuincd, when we take intw consideration the faets that plonghing can he done more chc'ply in the fall than in the spring; that fall ploughing servos to rive a more even distribution of labour; and that nlougling after September the twentieth is an effective means of combatting the cutworm. Very little trouble, due to this pest, being experienced on the fall ploughed sections of the plots.

(3) This experiment was conducied on a sandy loam soil; and while the fall ploughed soil ran together somewhat during the winter the two discings, in the spring, was all that was required to put it in first class condition for planting.

(4) The poor vields on plots number four were due, at least in part, to the fact that these plots were hadly infected with the root rot in certain sections.

\section{Fertulzer Tests on Flue Claed Tobicco.}

From thirteen to serenteen plots, one-twentieth acre in size, were staked off on land as nearly uniform as could be found. All of these plots, with the exception of one eleck plot and ore plot on which a ready mixed commercial fertilizer was used, had home-mixed fertilizers of different formulae drilled into the rows hefore the tobacco was set out. The rows were laid off in such nuaner that earh plot coutained the same number of hills of tobacco. The tobaceo on these plots was all planted and harvested on the same days, cultivated alike, and cured under as nearly the same conditious as possiblc. When harvested the tchaceo irom each plot was tagged and kept separate from that on the other plots until it had been stripped and weighed.

No manure was used to supplement the fertilizer on any of these plots. The data concerning these plots will be found in the following tahles:-

Table 1.

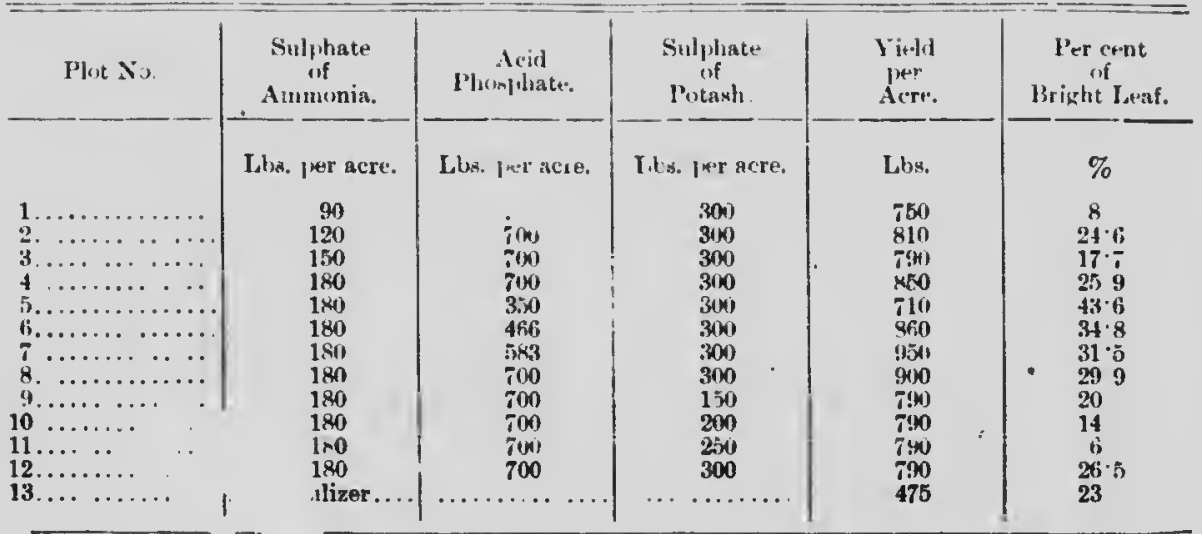


Table 2.

\begin{tabular}{|c|c|c|c|c|c|}
\hline l'lot Xo. & $\begin{array}{l}\text { Sulphatu } \\
\text { of } \\
\text { Amnomia. }\end{array}$ & $\begin{array}{c}\text { Acid } \\
\text { Phowphate. }\end{array}$ & $\begin{array}{c}\text { Wulphate } \\
\text { of } \\
\text { potanh }\end{array}$ & $\begin{array}{l}\text { Yiold } \\
\text { per Acre. }\end{array}$ & $\begin{array}{c}\text { Wer cent } \\
\text { of } \\
\text { Bright Ieaf. }\end{array}$ \\
\hline 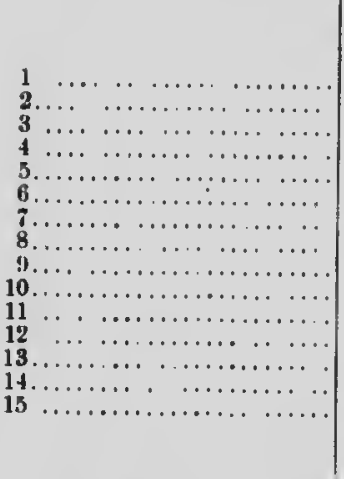 & \begin{tabular}{|c|} 
I.bn. ler acre. \\
180 \\
180 \\
2110 \\
240 \\
180 \\
180 \\
140 \\
180 \\
180 \\
180 \\
180 \\
180 \\
$1,000 \quad 1 \mathrm{~b}$ \\
180
\end{tabular} & 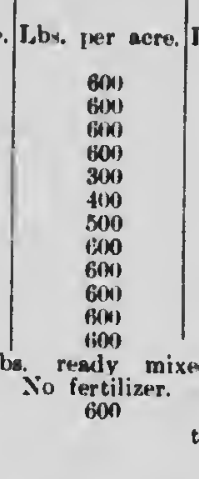 & 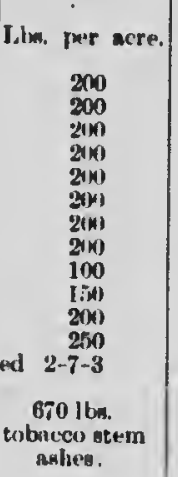 & 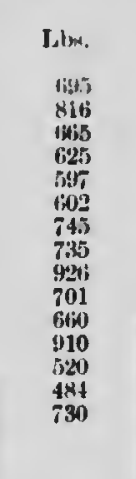 & 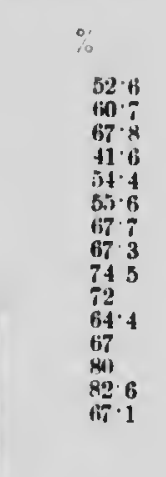 \\
\hline
\end{tabular}

Plots 1, 3 and 4 were badly damaged by exeessive moisture so the results obtained on them eannot be considered.

Table \$.

\begin{tabular}{|c|c|c|c|c|c|}
\hline Plot $\mathbf{N}_{0 .}$ & $\begin{array}{l}\text { Sisplinte } \\
\text { of } \\
\text { Ammonia. }\end{array}$ & $\begin{array}{c}\text { Acid } \\
\text { Phomplate. }\end{array}$ & $\begin{array}{l}\text { Sulpliate } \\
\text { of } \\
\text { Potash. }\end{array}$ & $\begin{array}{c}\text { Yield } \\
\text { per Acre. }\end{array}$ & $\begin{array}{l}\text { Per Cint } \\
\text { of } \\
\text { Brixlit Latif. }\end{array}$ \\
\hline 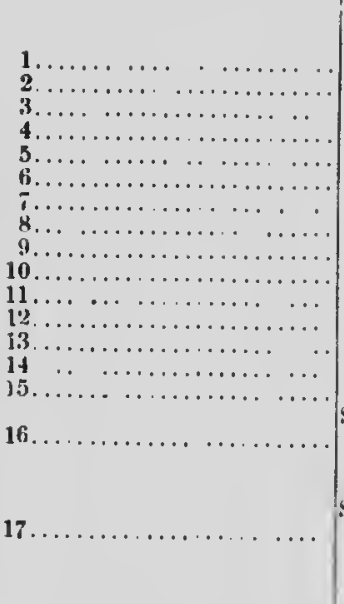 & 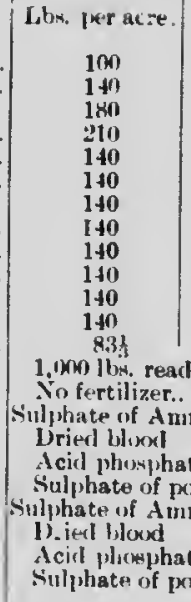 & 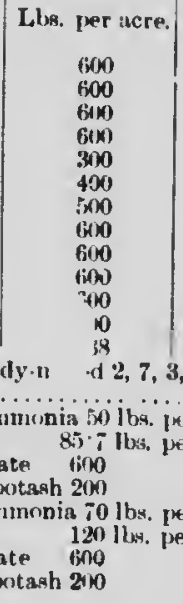 & 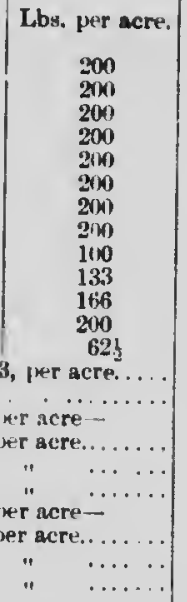 & 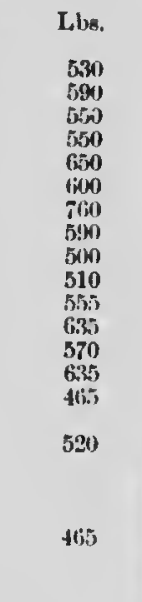 & $\begin{array}{l}88 \cdot 6 \\
85 \cdot 5 \\
84 \cdot 2 \\
75 \cdot 9 \\
81 \cdot 5 \\
81 \cdot 6 \\
86 \cdot 4 \\
88 \cdot 1 \\
79 \\
78 \cdot 4 \\
82.8 \\
92.1 \\
80 \cdot 7 \\
88.1 \\
82.7 \\
81 \cdot 7\end{array}$ \\
\hline
\end{tabular}

Plots 16 and 17 have the eame plant food content as plots 1 and \& respeetively. Plot 17 . was very badly missing.

General Discussion and Recommendations.-Tables 1, 2, and 3 are records of the results of experiments conducted in the years of 1916,1917 , and 1918 respectively; and sinee there was a great variation in the seasons of those years and the experiments 
were conuacted on different picees of land each year variations in the results obtained were expected.

It will be notieed that the first twelve fertilizer plots in the tables may be divided into three groups of four plots each, namely: nitrogen, acid phosphate, and potasl plots respectively. In each of these groups two ingredients of the fertilizer were kept eonstant while the third ingredient was varied.

From the results recorded in Table 1 the best formula, so far os yield is coneerned, would apparently be:-

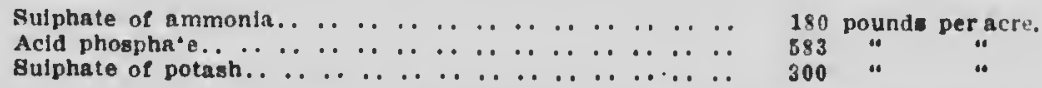

However, from plots 10 and 11 we see that an inerease of potasl over plot 9 gare no corresponding inerease in yield; consequently, it would seen advisable to cliange the amount of potash to be used in the above formula from 300 pounds to 150 pounds per aere.

On the basis of bright leaf produeed the best formula in Table 1 was:-

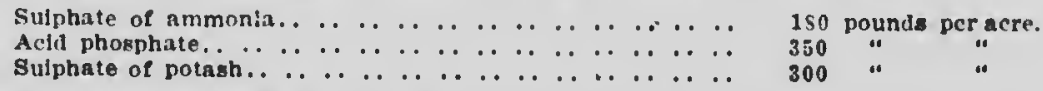

Ilowever, these figures as regards acil phosphate are in direct opposition to the known tendeney of aeid phosplate to brighten the eolour and should not be taken too eonclusively.

From the results recorded in Table 2, the best fornula for both yield and colour would apparently be:-

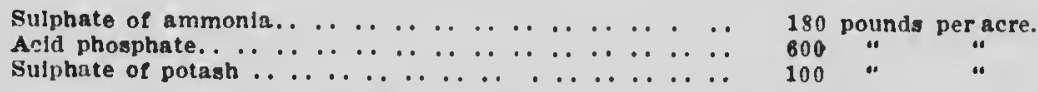

Computing the differenee between the value of the tobaces grown on plots 9 and 14 (Table 2) : t thirty-five cents per pound and subtraeting the cost of the fertilizer, eomputed on the basis of $\$+0)$ per ton for potash, $\$ 100$ per ton for ammonia. and $\$ 22$ per ton for acid phosphate, we find we made $\$ 119.10$ clear profit per aere for the use of the fertilizer.

By comparing the results obtained on plot 15 with those olbtained on plots 2,8 and 11 (Table 2), all 0 : which had the same fertilizer applied with the exception of plot 1.5 on which enough tobaceo stem ashes were substituted for sulplate of potash to give the equiralent of potash, it would seem that the ashes nay safely be used as a substitute for that ingredient.

From the results recoried in Table 3 , the best formula for sicld would apparently consist of :-

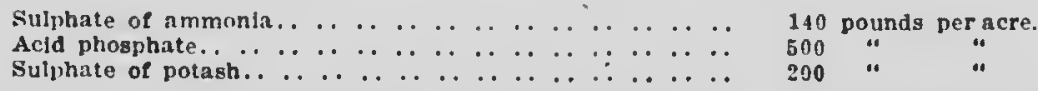

The results reported in Table 3 were obtained during the season of 1915 which was a very dry season and a very poor one for fertilizers to show up to the best adrautage. However, by computing the difference between the ralue of the tobaceo grown on plots F and 15 at fifty-five eents per pound and substraeting the cost of the fertilizer, $\mathrm{cmm}$ puted nu the basis of $\$ 100 \mathrm{pe}-$ ton for potash, $\$ 110$ per ton for ammonia, and $\$ 24$ per ton for aeid phosphate, we find that there was a net profit of $\$ 109.55$ per aere for the use uf the fertilizer.

In comparing the results obtained on plots 13 and 14 (Table 3), o. between home mixil and ready mixed fertilizer. it would seem that the source of ar. annia nsorl hy the manufacturer mas better adapted to the production of tobaceo, in dry seasons, than the souree used in the home mixcd fertilizer. 
From the results olbtained on plot 16 as ampares to those olotained on plot 1 it would seem that dried blood was a little slow in liberating its nitrogen for the neo of the plant. IIuwever, in more liumid geasons there is a possibility of this defect being: resnedird.

From the results recorded in the foregoing tables the following general eouelusions were deened justifialble.

(1) All of the fertilized plots gave better yields than the unfertilized plots.

(2) On the fertilizer plots which gave the largest yie'ds there was a net profit of from $\$ 2$ to \$3.81 for every dollar spent in fertilizer.

(3) On these soils, whirh are reprrarututive of the heavirr trpes of soil used in the problution of flue-cured tobacen, it would serm that a eouplete fertilizer is reruirel to secure the pnaximum yield and the best puality.

(1) These results alsn indieate that for lonth sield and quality, on the heavier soils, the following mixture is best:-

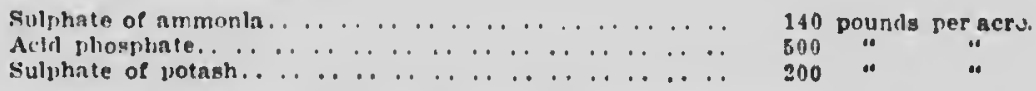

This formula gives a total if $\$ 40$ pound of fertilizer per arre; however, the plant food eontained in that $84^{\circ}$ poumds is approximately epuivalent to the plunt fond enntained in 1,100 pounds of a roaly-mixed fertilizer with an analysis of 3 per ecut ammonia, 8 per eent phosphorie acid, and 9 per eent potnsh.

\section{Fehtulzi:r Tests on BL.zL:Y.}

From sixteen to eighteen one-twenticth nere plots wero staked off and the same preenuti as taken and eultural method-insed as on the fertilizer plots of flue-eured tobaceco. tubles:-

The fertilizers used and the results obtained will be found in the following

T.1BLL: I.-Cur) 191\%.

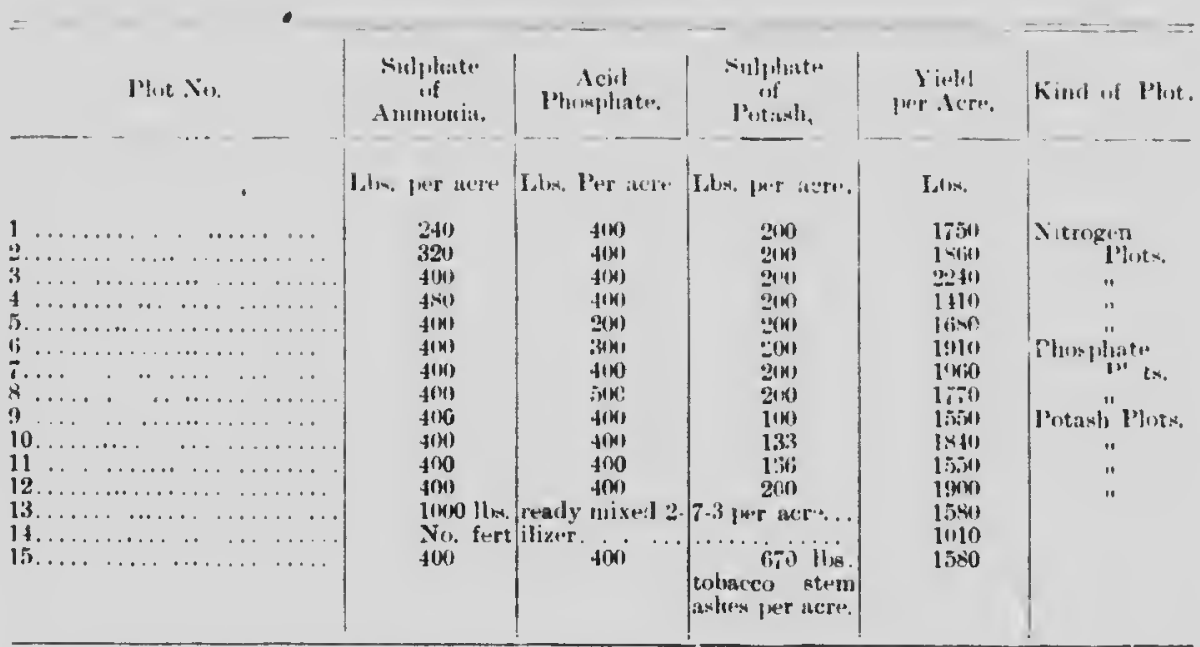

Plots 4, 5, 6, 8 and 9 were slightly damaged by exeessive moisture.

Plotg 11 and 15 were bndly damaged by water.

The fertilizer on these plots was not supplemented with manure. 
T.งH.t: 2.-Chop 1019.

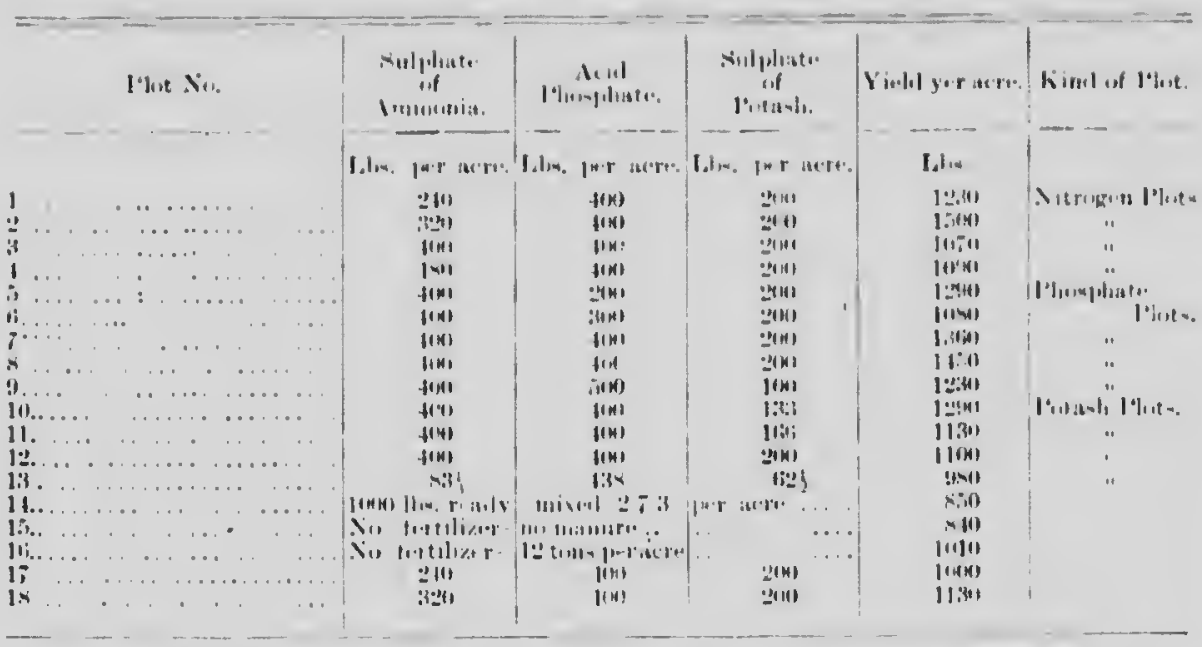

Plots 17 and 18 had 12 tons of manure per nere, ench, to supplement the fertilizer. The fertilizer on the first 15 plots was not supplemented with nunure.

lirom the yields on the plots it will readily he seen that the soil lackel uniformity. This was more largely due to the rolling charaeter of the soil, st me pluts being slightly higher and sutfering more from drought than others, than to differences in fertility.

(ieneral diseussion and reconmenlations: from the results shown in Tuble 1 the brst furmula would apluarently consist of :-

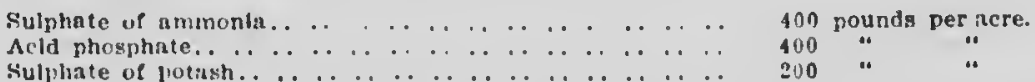

By computing the ditference between the value of +1 se tobaeen grown on plots 3 and 1 at twenty-tlire cents per pound and subtracting the ent of the fertilizer, cum. puted on the hasis of $\$ 100$ per ton for potash, $\$ 100$ per ton for ammonin, and $\$ 22$ per

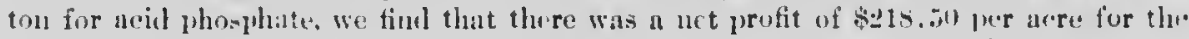
use of the fertilizer; or an net protit of $\$ 3.38$ for every doll $\mathbf{r}$ spent in fertilizer.

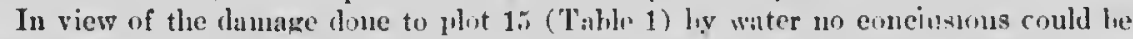
drawn regarding the substitution of tuhace stem asles for sulphate of motas.

From the results recorded in Table 2 the lest formula for Burley would apparently be:-

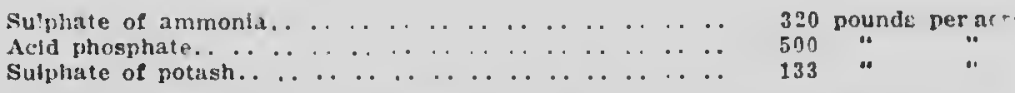

By eomputing the c: :fference hetween the value of the tohaeen grown, is 2 and 15 at thirty-five cents ner nound and subtracting the eost of the fert . con-

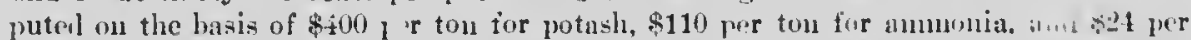

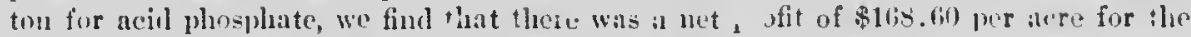
use of the furtilizer: or $\$ 2.70$ for every dollar spent in fertilizer.

On comparing the results obtain d nn plots 13 and 14 , or between ready-mixed and home-mixed fertilizers, both of wh: 2 eontained the sume amounts of plint fond we see that there was an appresicise $i$ ierease in yield on the hone-mixed fertilizer plrit over the rendy-mixed fertilizer plot.

While plots 17 and 18 were fertilized with a mixture having the same plant food content as that applied to plots 1 and 2 respectively, and in addition receired a sup- 
plemestary application of munure at the rate of 12 tons per acre, the yield $n n$ the $t w o$ formor plots wils not so high as on the litter plots. Thi was prolmbly due to the faet that plots 17 and 19 wero higher and drior thun plots 1 and 2 and too unfortunntely the murure applied to those plots dill mot deay anickly emongl to exert mnch influence on the crop. tilizeml.

All of the fertilized plots fuve better results than the plots whieh were not fer-

For the reneral run of unnumured soils the following formuln should prove to lie protitnhle:-

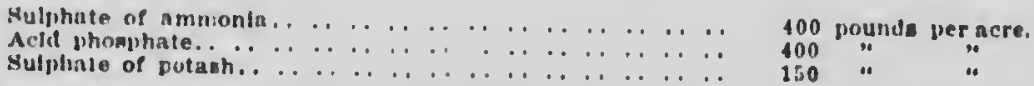

On the suils which lad leen nanured liberally the amount of sulphute of ammouin

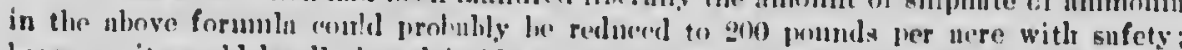

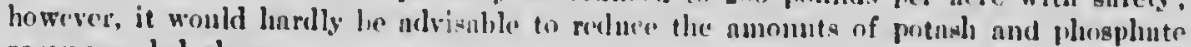
recoumunended above.

\section{Trinsplastive.}

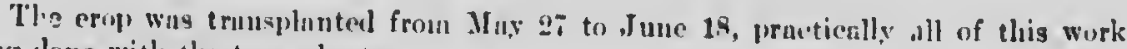
being done with the trunsulanter.

While in ordinary sengons no clifference wos noted betwen the vields of the early mul the lute planted erops it was olsorred that the crops plented carly aud liarvested early eured up the brightest molour.

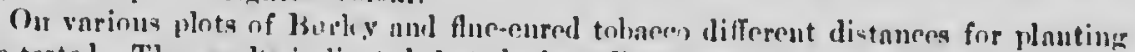
were tested. The results indiested that the iest distanerg for transplanting the varions tyines of tobneco were as follows:-

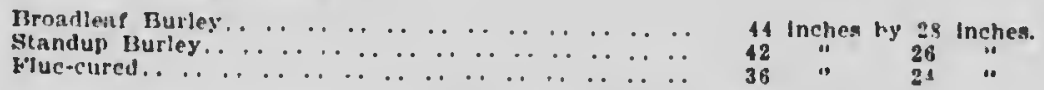

While the distunee resommended for trumsplunting the the-eured varieties muy lor ralher close for the lighter soils of the distriet for the locary soils, on this Stution, it is the hest mothod we have for overeoming the tendency of the tobareo in grow ton coarse and heavy and still ohtnin n maximum yicld.

\section{Cutivitiox IND TopPive.}

Tiwe first heciug and enitivation wo given the tobaen ubout eiglit dnys after it was set out. Ifter this the tobacro was cultivnted frefuently enough to kerp down the wreds and graes and aloo kerp a dust mulch formol. Ill enltivition was stopned nfter the toliaceo had been toppeel. To continue the cultivetion after topping has lieen foumd to delay the ripening preese and is the fore detrimoutal, ns a general thing.

Topping una done from . Tuly 19 to August 10. as soon as the majority of the plants had begun to hud ont. In some plots it was nemessary to repeat this operation due to the lark of uniformity in the buthling out of the plints. At egleh topping after the first the plants were topped about two leaves lover, than the first, in order to enuse the erop to ripen more uniformly.

Postponing the topping operation, as is sometimes done, until a large nunber of the plunts have flowered ont can not be ton strongly eondemned. To do so not only caluses a loss of plant food but also retarda the ripening - oress.

\section{Growise Tonirro Sked.}

as quantitios of tobacen serd of the different varieties were produreel on the Station. In produeing these seed large numhers of plunts were seleeted and the seed 


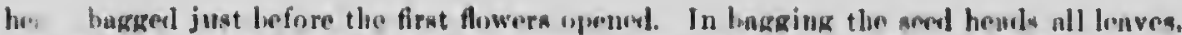
nue. re, and laternl hranches were removed from the top of the plunt until whly ther

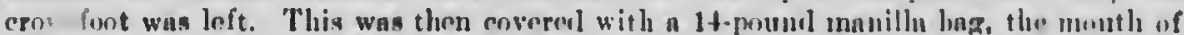

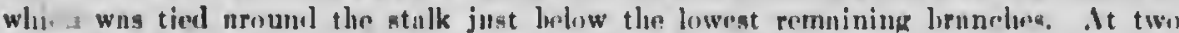

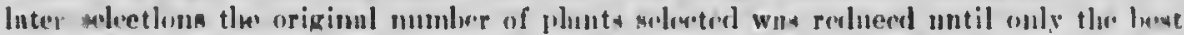

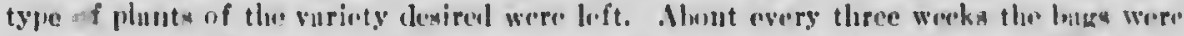

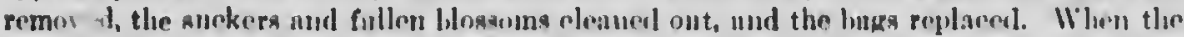

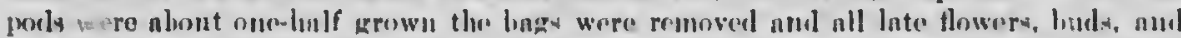

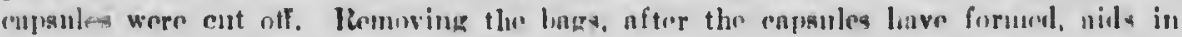
mnturinus the secel licuds enrlier.

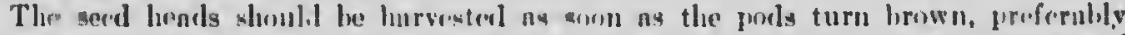

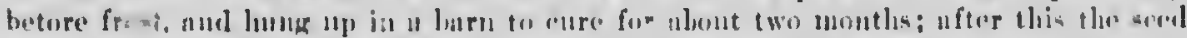

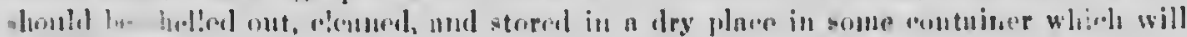

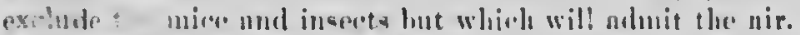

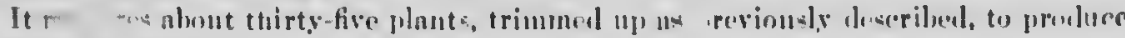
onp pusurat; and.

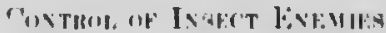

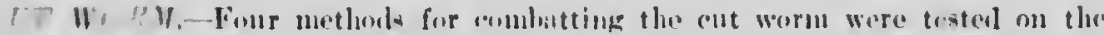

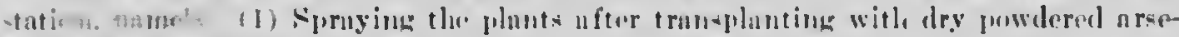

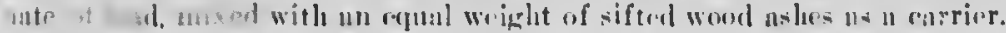

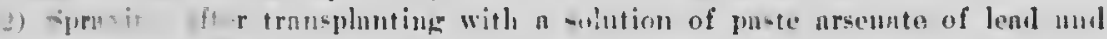

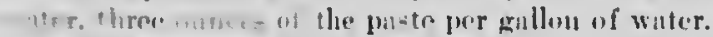

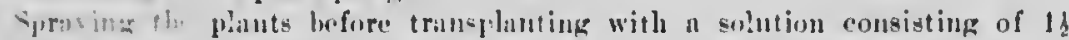

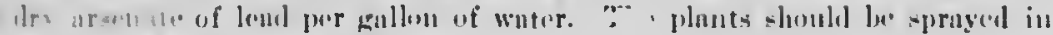
the wis to dre before breing se't out.

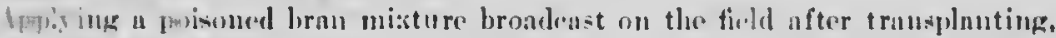
... I is i! fallowing proportions:-

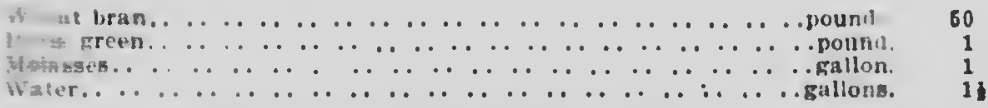

nel ime. - While this experinent las hardly becu rum loug cuenule to urrive

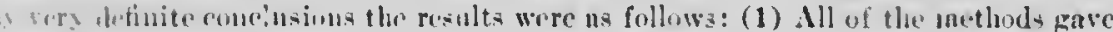

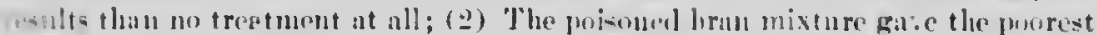

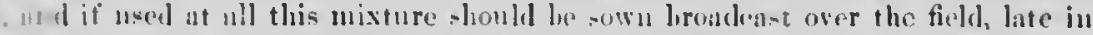

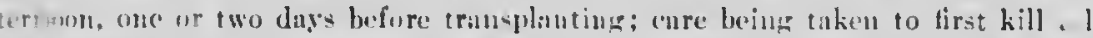
athl grmes: (3) Spraying the piants with the ursenute of lend solution before ushouting was apporently the most effective of the treatments.

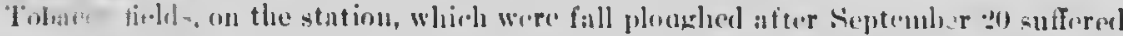
practically ing ry from the ent worm and fall ploughing is strubely recommended us a rontrut 1:tisure.

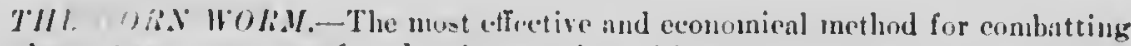

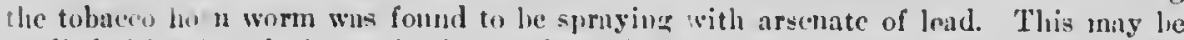
applied either in solution or in the powdered form. Jp nutil the tobarco is nbout half grown it c:an be sprayed very effectively with the solution in a spriy enrt which sprnys four rows sin'ultaneously. For this six pounds of powdered arsenate of lead to one hundred gallons of water is usually sufficient.

After the tobaceo beromes larger the top and middie leares so nenrly eover the hottom leares as to ronder the cart and sobution inefiecive. It is then thint the dist gun prores its value. For use in the dust gmu the powdered arsenate of lend is mixed with an equal quautity of dry eifted woor ashes; or nir-alakerl lime if the ashes nre not to be obtnined. The powder is then npplied early in the morning while the dew is on 
the tobaces, the operator holding the nozke of the dust gun at auch an angle an to hring it about the middle of the plant. For tobneeo nearing maturity six poumds of arsenate of lend is required per nere: for smaller tubaceo four and ono half pminds

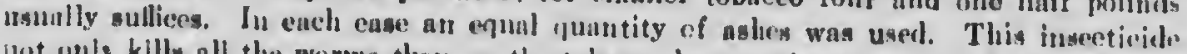
wot only kills all the worms then on the totaceo but contirnes to kill all which hated for several dlays aftor it is upplied.

Therc are severnl forms of arsennte of lend on the market and as all are not suit. uble for apruying tobnece the grower should deanul the form having a guasanted unalysis of not lews than thirty pre eeut ursenie oxide of which not more thun one pure
"ent is water goluble.

\section{Dratakin of Tomicro.}

Mosaic Disens",--The Mosnie Disenwe conumonly known as "Culien," “ Frenching." und ly various other local names was (pute prevalent in the tohnew crops some pasous: it heing most enmum in ruther wet yeura or in low wet regions in the fields. It is usparently breg infections and a hrae number of healehy plunts could he infected from a siugle disensind plant in the operntions of topping and suckering. Since this diarase attacks the youngest fastest growing purts of the plnnt it is rencrully most in evidenee on the top leaves. kiving them a charaeteristic mottled erinkly npmearanee, the disease still being in evidrnee after curing in the laek of elusticity of the lenf.

In nu experiment condueted to determine the power of tobnceo seed to transanit the divense to plants producel from that seed the secis of a Mosaicel plaut wrs sown and after the plants, from that seed, had develojwd suftieiently they were trunsplanted to the field. Appurently thrige plants were entirely free of the disease as not a single plant : bowed sigus of heing infeeted throughout tho growing senson.

In an experiment condueted, in eo-operation with Mr. F. C. Roust, rulative th the infectiousues of the Mranie Disease nll of thr infeeted plants were pulled out of some plots of tohneco early in the seasın, while in the other plots no infoeted plunts wire removed. The nur: hep of infected plants was reenrded in each and before harveating the plots $n$ scennd comut of dirnised plunts was mude. During the topping and suekering operations "upe w. t.sken unt to inforet the plants in the plots from outsicie sourees. The results of the "o:..sts indiented that the disease conld be held in eheck by pulling
out the disensme plants early in the senson.

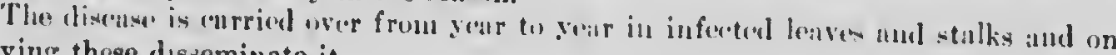
decaying these disseminnte it.

Ilethols of coutrol eonsist of usiug muly fresh soil for the proluction of plants. sterilizing seed beds, rotating erops, and where a field is not too bully infected pulling up the diseased plauts as soon as diseovered.

The l'oot liot.-The tobaeeo root $\mathrm{r}_{\text {... }}$ coused by the fungus Thiclaria bnsicola (B \& Br.) Znpf, was futite prevalent in the tobacen fields of this seetion during the past

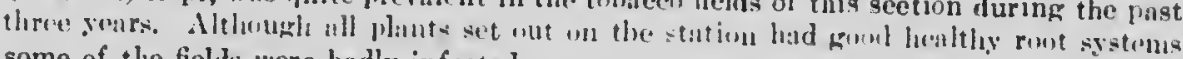
some of the fields were badly infeeted.

This fungus attaeks the entire root systena but is kencrnlly more in evidenee on the voung fibreus roots causing then to deeny; whercupon these roots cense to function ats food earriers and, as a result, the plant is stnried. The degree of starvation depends upon the extent to which the field and plant are infeeted, the elimatic conditions pre. railing nt the time of transplanting, and the robustness of the plant. Some plants died; however, with the majority the roots apparently functioned just long enough. before leeoming disensed, to keep the plant living but not lnng emough to enable it to make any growth. The disensed plants generally remained sinall until late in the senson when they began to grow; however, such plants never attnined the size which a normal plant did and usually were harvested green of necessity. 


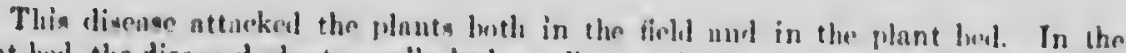

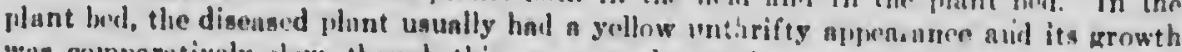
was comparitively slow, thouph this was not alway the cisn. Often upun exnmina.

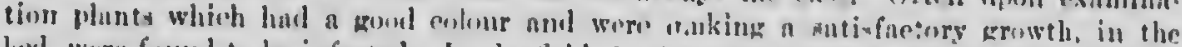

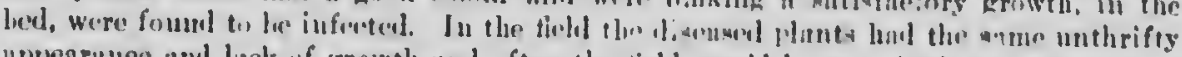

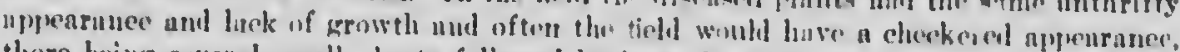

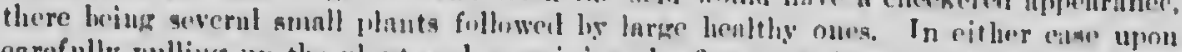

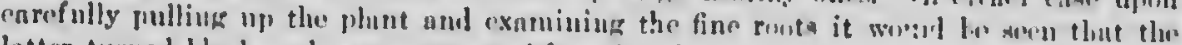

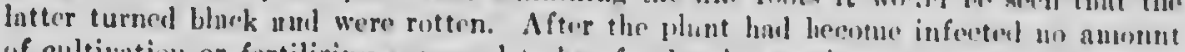
of cultivition or fortilizing upenrel to he of valuo in startius: it to grow. Howewr.

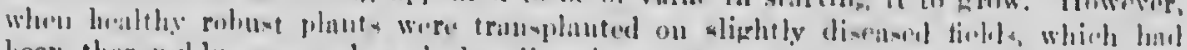

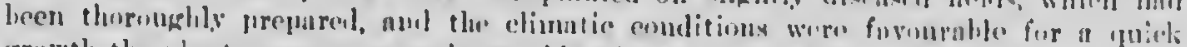

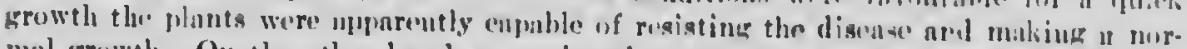

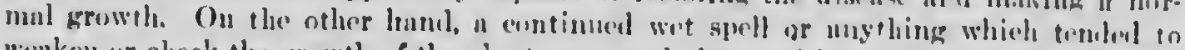

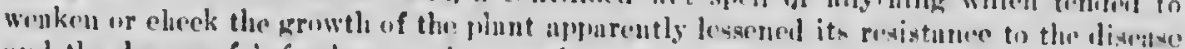
und the degree of iufection wis incrensesl.

Mothuls of entrol consisted of sterilizing the plunt heds thorouglyly, not usiag

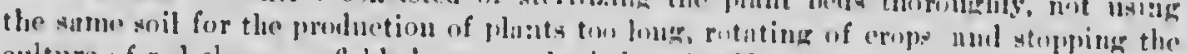

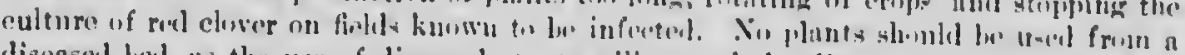

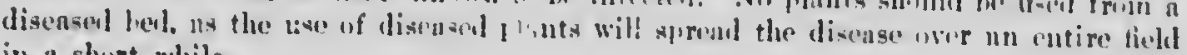
in a shurt while.

Bod liot or Damping-off.-The rotting or dampingent of the young serellings in

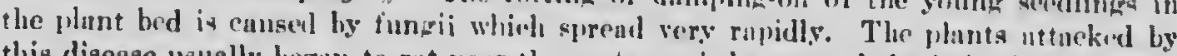
this disease usually began to rot near the burfuce of the gromend the inferetion, in some

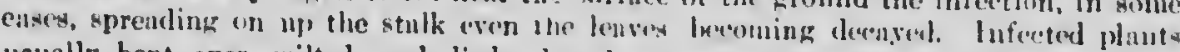
usually bent over, wilted, and died; thongl snne recosered giving evidence of the nttack by a browniah dendened aren on the stalk near the root. Sueh plants should he discarded as they feldom prove satisfaetory when transplunted. The disenas wus most prevalent in thickly seeded lieds which were rery inniat and lacked ventil ninn.

Sterilization of the bed and seeling thinly were the must offoctive all thula for preventing the disense. After it oceurred it wis elecked by throwing wut the in. fecter planta, loweriug the teuperature ly ventilating the bul well, aubl allowiug

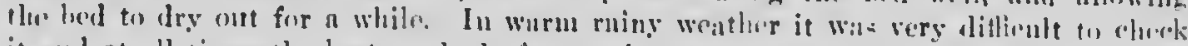

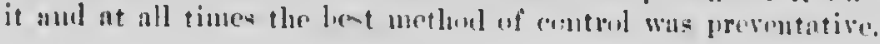

\section{H.om testivis.}

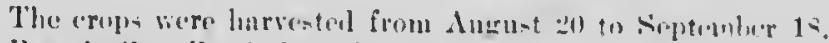

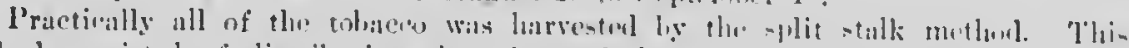

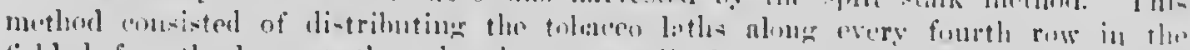

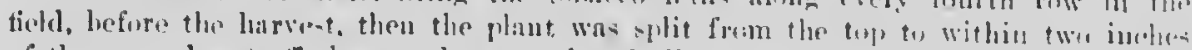
of the gromul. cut oft rose to the gromml and allowed to lin where it foll untit it hat

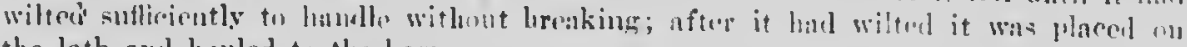
the lath aud lauled to the harn.

Sume of the crop waz spuddel or needled for compotrians. and it wa fouml that the tobaleo which was spulded repuirel from two to four wereks longer to cure than that the stalks of which were split; and too the leaves on the stalls which were spudder eured up a darker colour than those on the stalls which were split.

It required two hours less labour per acre to harvest by the split stalk methorl than by the spudding methud.

\section{Sc.fFfolonisg rs Dimect Curiva.}

Plots of Burler were senffolded in the field immediately after being harve-ted for different periods of time and compared with Burley cut at the sume time ancis 
lmuled to the baru as soun as wilted. It was found that Burley eould be scuffolded in the field snfely for ubont three dnys, in fair weatler, and a little yuieker and brighter enre obtaind than when the tolnaso wis lauled immediately to the harn. After thint three cings was mp tho tobnees began to talie on w weather beaton appearnuce and redden up considerably.

Tho chicf value of salfolding tobneen in the field lies in the fact that it is at ureat suver of time mod barm space. The tobaces benomes thoronglily wilted an the

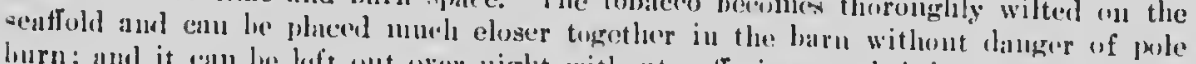

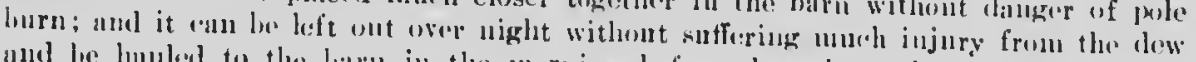

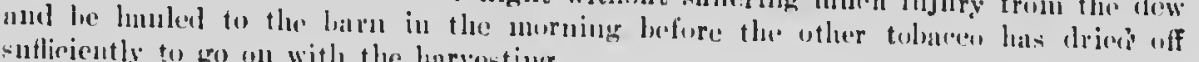
snfliciently to go an with the harvesting.

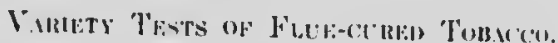

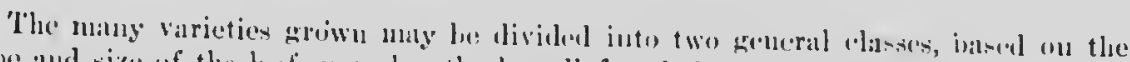
-hape and size of the leat, latumly: the liruallef and the natrub-leaf tyjes.

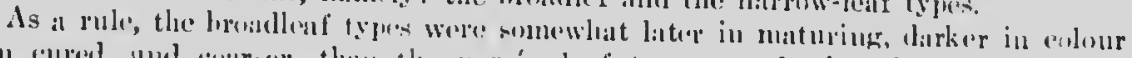

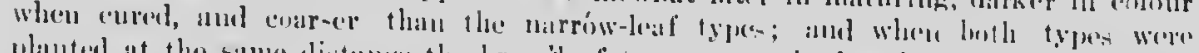

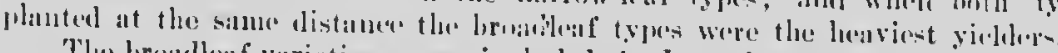

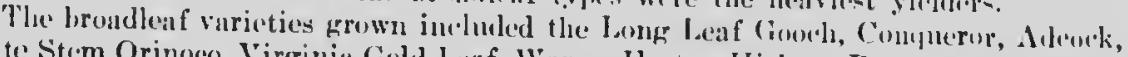
IIhite Strm Orinoeo, Virginia Cold leaf, Warne, Hester, Ilickury Pryor, and Crituher.

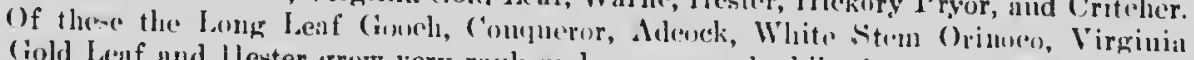

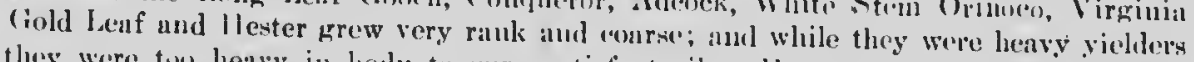

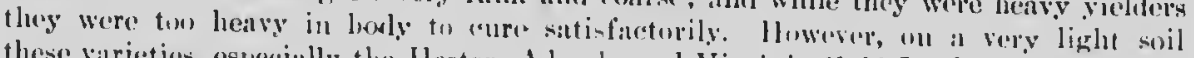

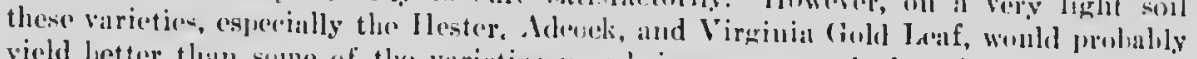

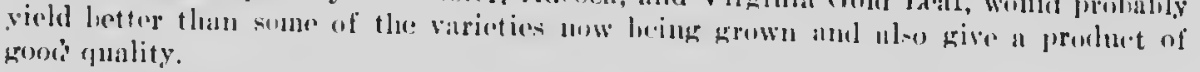

The Warue is about the most satisfaetory variety for the general run of soila, griving a very smooth lenf of goon huly and a good yicld; however, it has a tendeney to cure up with a dull face aud on leavy soils it grows ratler rauk.

The Ilickory Pryor and ('ritoher are quite sinilar in their eliarneteristies; both will grive a cured leaf of a bright flashy faco and are fair yichlers, thongh not so good as vichlers as the Warne. Of the two the Hickory Pryor is the best yielder and has the smoothor leaf, and on the heavier soils gives the nost sitisfactery rosults of any of the brombleaf varieties.

Th" narrow-lenf varictices grown inchulel Flanunan and Gopher skin. The

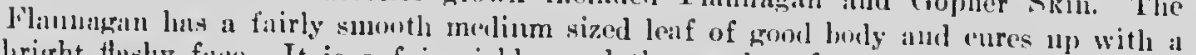
bright fishy fice. It is a fair yieller mul the results of the experimenta indieate thut, on the havior types of soil, if it is planted a little eloser than is eustonary in panting the broml-leaf varieties it will yield just as well as the hatter and give a briglitor andurarel loaf of good body.

The Ciopher skin has a sualler and little roneloer type of leaf than the Flannagan. It rures up loright mul while it is a fair violeler tle puality uf the leaf is mot enito so frood as that of the Flanuaginu.

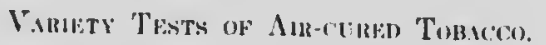

Fin the generai crop of Burley three vnrieties were grown, numely: Broadleaf. Sitation Standup, and Johnson's Resistant Burley.

The Station Standup Burley is elanracterized by a long, fairly uarrow, pointed leaf which grow somewhat ereet. While it is a little smuller typo of plant than the Broal-lenf Burley if it is planted a little eloser than the latter the yield obtained wil! lie about the same, and the Standup always surpasses the Broallenf in the fiual aolour of the eured Ienf. The Standup is esperially adapted for plinting on dark heary soils and will give a fnir colour on sueh soils when the Broadlenf would be quite dark. 
The Broadleaf Burley las rather brond drooping loaven, in a groul yidller, mutures a little later than the Standup, and oul account of its heuvior sup content eures up darker thau the latter.

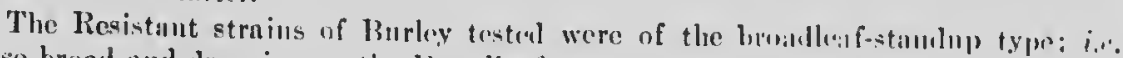

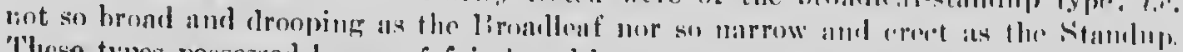

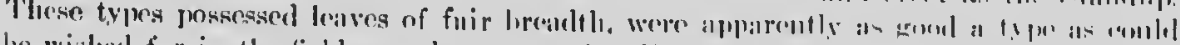

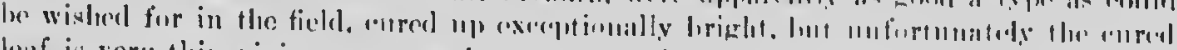

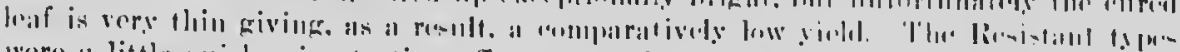

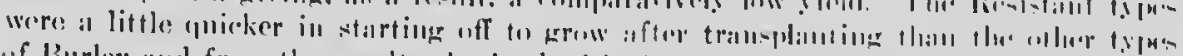

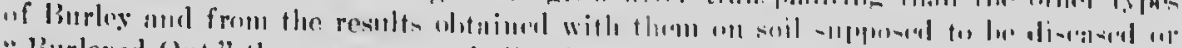

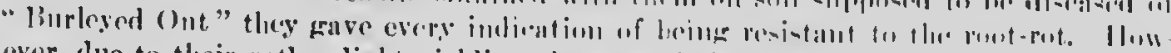

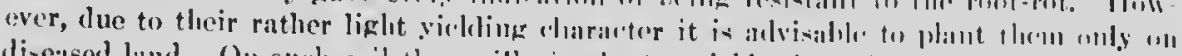

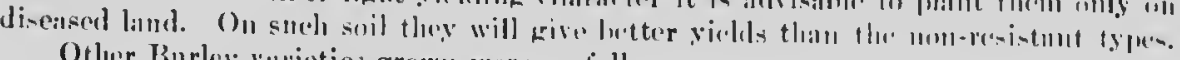

Other Burley varieties grown wore as follows:--

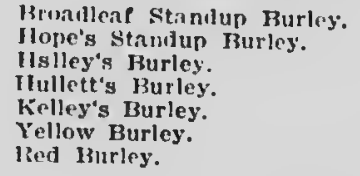

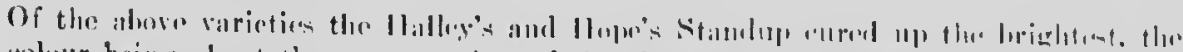

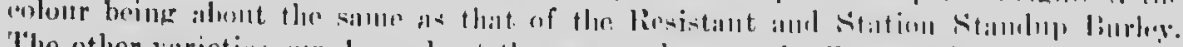

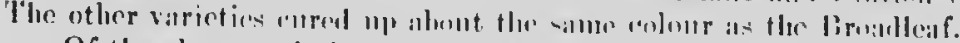

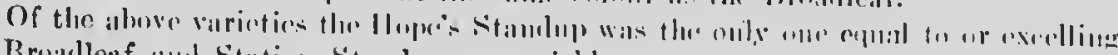

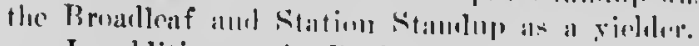

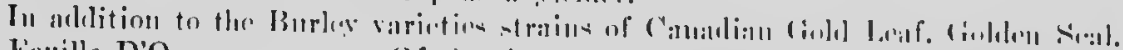

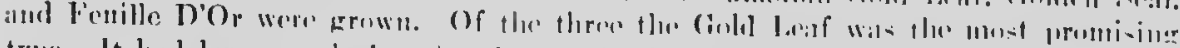

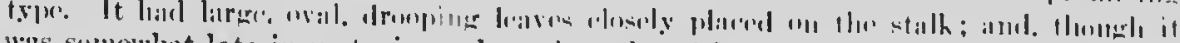

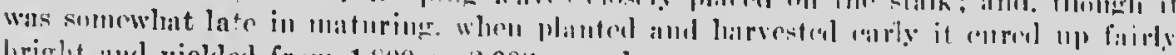

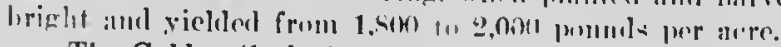

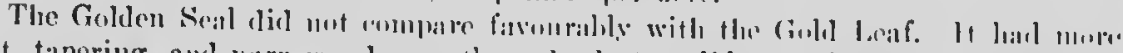

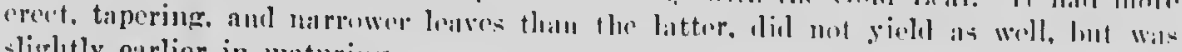
sliglitly carlier in maturine.

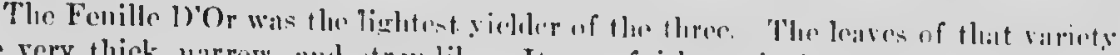

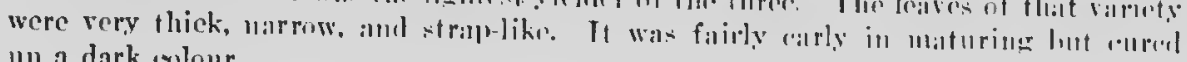
ו1 i dark iqulour.

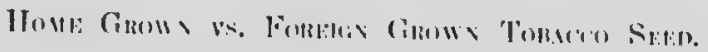

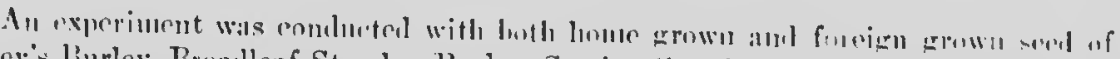

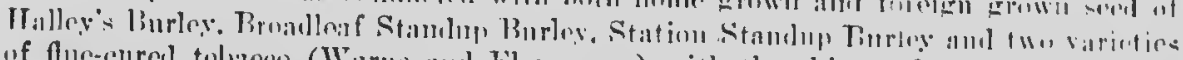

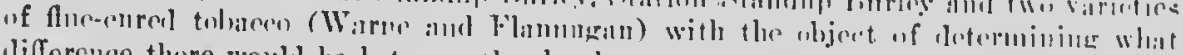

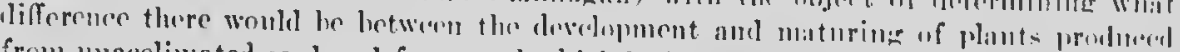

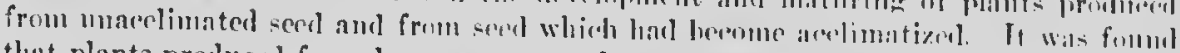

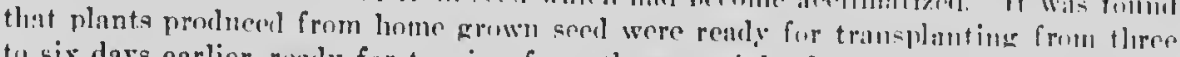

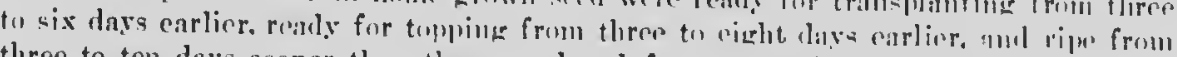

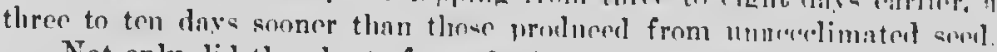

Not only diel the plants from the home grown weol ripoul earlior than these produced from foreign grown seed hut the former ripened more uniformly than thu"
latter.

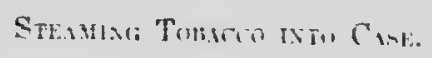

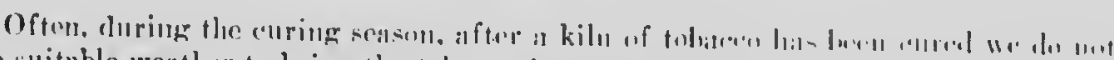

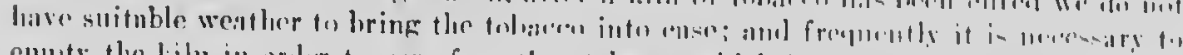

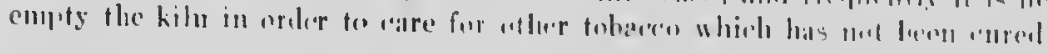




\section{2:}

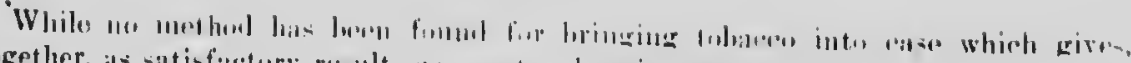

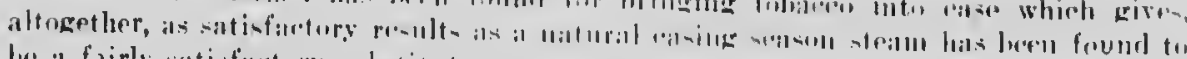

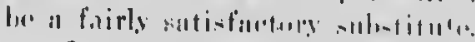

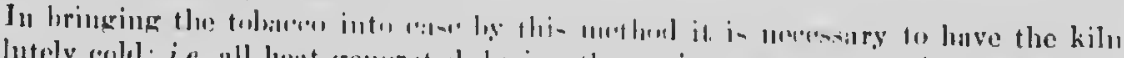

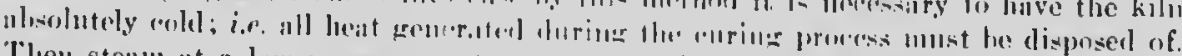

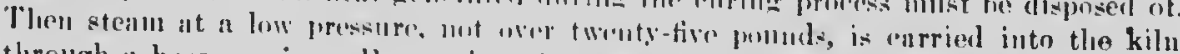

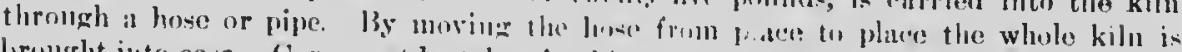

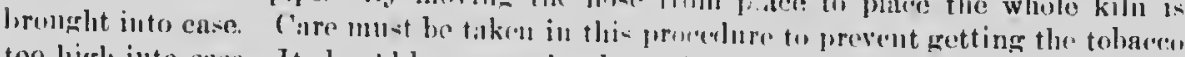

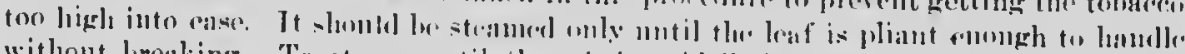

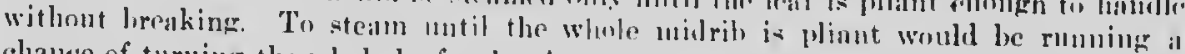

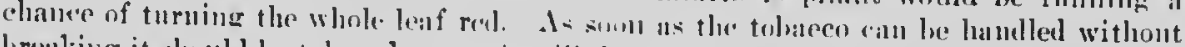
lireiling it sumld be takell down als it will dry ont wery fast when it has been steamed intu case.

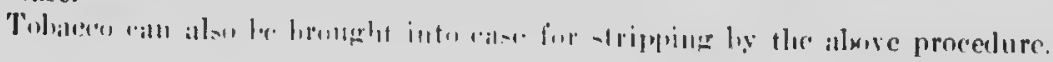




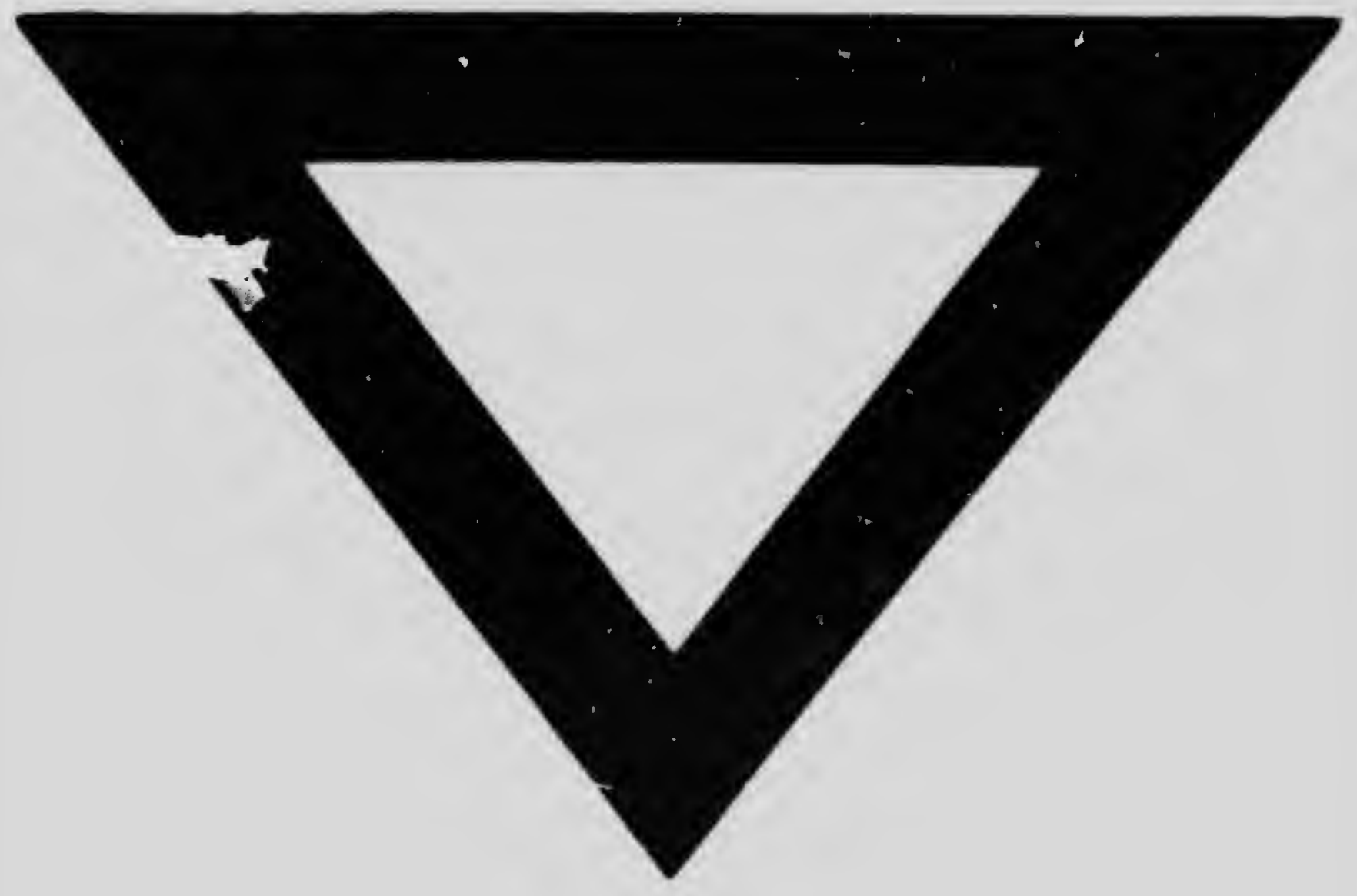

